\title{
The Phylogenetic Intrarelationships of Spiny-Rayed Fishes (Acanthomorpha, Teleostei, Actinopterygii): Fossil Taxa Increase the Congruence of Morphology with Molecular Data
}

\section{OPEN ACCESS}

Edited by:

Andrey Tatarenkov,

University of California, Irvine, USA

Reviewed by:

Adriana López-Arbarello,

Ludwig Maximilian University of

Munich, Germany

Guillermo Orti,

George Washington University, USA

Francesco Santini,

University of California Davis, USA

${ }^{*}$ Correspondence:

Donald Davesne

donald.davesne@earth.ox.ac.uk

${ }^{\dagger}$ Present Address:

Donald Davesne,

Department of Earth Sciences,

University of Oxford, Oxford, UK

Specialty section:

This article was submitted to Phylogenetics, Phylogenomics, and

Systematics,

a section of the journal

Frontiers in Ecology and Evolution

Received: 18 August 2016

Accepted: 28 October 2016

Published: 14 November 2016

Citation:

Davesne D, Gallut C, Barriel V, Janvier $P$, Lecointre $G$ and Otero $O$

(2016) The Phylogenetic Intrarelationships of Spiny-Rayed

Fishes (Acanthomorpha, Teleostei, Actinopterygii): Fossil Taxa Increase the Congruence of Morphology with

Molecular Data.

Front. Ecol. Evol. 4:129.

doi: 10.3389/fevo.2016.00129

\section{Donald Davesne ${ }^{1,2 *}$, Cyril Gallut ${ }^{1}$, Véronique Barriel ${ }^{2}$, Philippe Janvier $^{2}$, Guillaume Lecointre ${ }^{1}$ and Olga Otero ${ }^{3}$}

\begin{abstract}
1 Institut de Systématique, Évolution, Biodiversité, UMR 7205 Centre National de la Recherche Scientifique, UPMC, École Pratique des Hautes Études, Sorbonne Universités, Muséum National d'Histoire Naturelle, Paris, France, ${ }^{2}$ Centre de Recherche sur la Paléobiodiversité et les Paléoenvironnements, UMR 7207 Centre National de la Recherche Scientifique, UPMC, Sorbonne Universités, Muséum National d'Histoire Naturelle, Paris, France, ${ }^{3}$ Institut de Paléoprimatologie, Paléontologie Humaine: Évolution et Paléoenvironnements, UMR 7262 Centre National de la Recherche Scientifique, Université de Poitiers, Poitiers, France
\end{abstract}

Acanthomorpha (spiny-rayed fishes) is a clade of teleosts that includes more than 15, 000 extant species. Their deep phylogenetic intrarelationships, first reconstructed using morphological characters, have been extensively revised with molecular data. Moreover, the deep branches of the acanthomorph tree are still largely unresolved, with strong disagreement between studies. Here, we review the historical propositions for acanthomorph deep intrarelationships and attempt to resolve their earliest branching patterns using a new morphological data matrix compiling and revising characters from previous studies. The taxon sampling we use constitutes a first attempt to test all previous hypotheses (molecular and morphological alike) with morphological data only. Our sampling also includes Late Cretaceous fossil taxa, which yield new character state combinations that are absent in extant taxa. Analysis of the complete morphological data matrix yields a new topology that shows remarkable congruence with the well-supported molecular results. Lampridiformes (oarfishes and allies) are the sister to all other acanthomorphs. Gadiformes (cods and allies) and Zeiformes (dories) form a clade with Percopsiformes (trout-perches) and the enigmatic Polymixia (beardfish) and Stylephorus (tube-eye). Ophidiiformes (cusk-eels and allies) and Batrachoidiformes (toadfishes) are nested within Percomorpha, the clade that includes most of modern acanthomorph diversity. These results provide morphological synapomorphies and independent corroboration of clades previously only recovered from molecular data, thereby suggesting the emergence of a congruent picture of acanthomorph deep intrarelationships. Fossil taxa play a critical role in achieving this congruence, since a very different topology is found when they are excluded from the analysis.

Keywords: Acanthomorpha, Teleostei, Actinopterygii, morphological phylogeny, Lampridiformes, Gadiformes, Zeiformes, Percomorpha 


\section{INTRODUCTION}

Nearly one third of modern vertebrate diversity is contained within Acanthomorpha, a group of teleosts (Teleostei, Actinopterygii) collectively known as the spiny-rayed fishes (Rosen, 1973; Nelson et al., 2016). The more than 15,000 acanthomorph species occupy every aquatic environment, with a strong preponderance in marine ecosystems. The phenotypic diversity of acanthomorphs is considerable: They include such widely divergent morphotypes as seahorses (Syngnathidae), flatfishes (Pleuronectiformes), pufferfishes (Tetraodontiformes), flying fishes (Exocoetidae), and oarfishes (Regalecidae). Several important model organisms such as the medaka (Oryzias latipes), the fugu (Takifugu rubripes), and the stickleback (Gasterosteus aculeatus) are also part of the group (Chen et al., 2004). Deciphering acanthomorph phylogeny is then crucial for better understanding patterns and mechanisms of diversification in vertebrates. However, it has proven difficult to resolve, as was pointed out in pioneering phylogenetic studies based on morphology (Greenwood et al., 1966; Rosen, 1973; Stiassny, 1986; Patterson and Rosen, 1989; Johnson and Patterson, 1993). Subsequent molecular phylogenetic studies have significantly impacted acanthomorph phylogeny (Wiley et al., 2000; Miya et al., 2001, 2003; Chen et al., 2003, 2014; Dettai and Lecointre, 2005; Li et al., 2009; Broughton, 2010; Betancur-R et al., 2013; Grande et al., 2013; Near et al., 2013; Malmstrøm et al., 2016), triggering the emergence of some new and increasingly stable patterns of relationships. However, many parts of the tree remain poorly resolved, notably for the deep intrarelationships of acanthomorphs, corresponding to a phase of diversification that occurred before the end-Cretaceous mass extinction event (Patterson, 1993; Friedman, 2010).

\section{CONTEXT OF THE STUDY}

\section{Contribution of Morphology to Acanthomorph Phylogeny}

In the late 1960s and 1970s, pioneering studies of morphological characters began to organize acanthomorph classification with a phylogenetic scope. Such was the case of Greenwood et al. (1966), Rosen and Patterson (1969), and Rosen (1973), the latter naming the clade Acanthomorpha for the first time. Along with subsequent works by Stiassny (1986) and Patterson and Rosen (1989), these successive studies contributed greatly to our present knowledge of acanthomorph evolution, notably by proposing major acanthomorph clades supported by morphological synapomorphies. Computed phylogenetic analyses of acanthomorphs based on taxon-by-character matrices began to be available in the 1990s, with studies by Stiassny and Moore (1992) and Johnson and Patterson (1993) who proposed a comprehensive hypothesis for deep acanthomorph intrarelationships (Figure 1A). Wiley et al. (2000) proposed a phylogenetic analysis using combined morphological and molecular data. Their morphological dataset is essentially based on Johnson and Patterson's, and their tree topology based on anatomical data alone (Wiley et al., 2000, Figure 8A-and not Figure $8 \mathrm{C}$ as stated in the article) does not contradict the original study because of a mere lack of resolution. Springer and Orrell (2004) explored acanthomorph relationships through the gill-muscle characters only, yielding a different topology that is weakly supported by their data. Mirande (2016) analyzed a large dataset of combined molecular and morphological data covering the diversity of actinopterygians (including acanthomorphs). However, this work does not include an analysis of morphological data alone; moreover, at the level of deep acanthomorph relationships, the parsimonious tree obtained from the analysis of molecular data alone does not differ from the proposed final hypothesis obtained with combined data, which suggests that morphological data did not fundamentally influence the combined topology. Other phylogenetic analyses using morphology alone were either based on a smaller subset of acanthomorphs, for example Gadiformes (Endo, 2002; Grand et al., 2014), Percopsiformes and related taxa (Murray and Wilson, 1999) and Zeiformes (Tyler et al., 2003; Tyler and Santini, 2005), or were centered on early fossil taxa (Otero et al., 1995; Otero and Gayet, 1996; Alvarado-Ortega and Than-Marchese, 2012; Davesne et al., 2014; Delbarre et al., 2016). Thus, to date no morphological dataset has been capable of challenging the results of Johnson and Patterson (1993) (Figure 1A).

\section{Current Knowledge of Deep Acanthomorph Intrarelationships}

Since the beginning of the twenty-first century, molecular phylogenetic studies have significantly revised acanthomorph phylogeny, including the deep intrarelationships at the base of the tree (Figure 1B). Acanthomorph phylogeny based on molecular data is simultaneously: (1) significantly different from what was proposed by the morphological data alone; (2) increasingly stable, due the repetition of some results from one independent study to another, and using different sets of markers; (3) still largely unresolved because the different molecular datasets have consistently diverged on many key points (Figure 1B).

\section{Acanthomorph Monophyly}

The taxa currently grouped under the name Acanthomorpha were initially treated as three distinct groups (Greenwood et al., 1966): Paracanthopterygii (see below), Atherinomorpha (including killifishes, flying fishes, needlefishes, silversides, etc.), and Acanthopterygii (centered on "perciforms"). These three groups were later united in Acanthomorpha, on the basis of the presence of true spines in dorsal, anal and sometimes pelvic fins (Rosen, 1973). Subsequent studies corroborated acanthomorph monophyly by adding morphological synapomorphies for the clade (Rosen, 1985; Stiassny, 1986; Stiassny and Moore, 1992; Johnson and Patterson, 1993). Molecular data, however, are much more ambiguous regarding the monophyly of Acanthomorpha. While acanthomorph monophyly has been supported by studies based on combined nuclear and mitochondrial markers (Wiley et al., 2000; Dettai and Lecointre, 2005; Grande et al., 2013), mitochondrial genomes (Broughton, 2010), and large datasets of multiple nuclear markers (Near et al., 2012, 2013; Betancur-R et al., 2013; Faircloth et al., 2013; Malmstrøm et al., 2016), it has also been questioned by studies based on mitochondrial (Colgan et al., 2000; Miya 

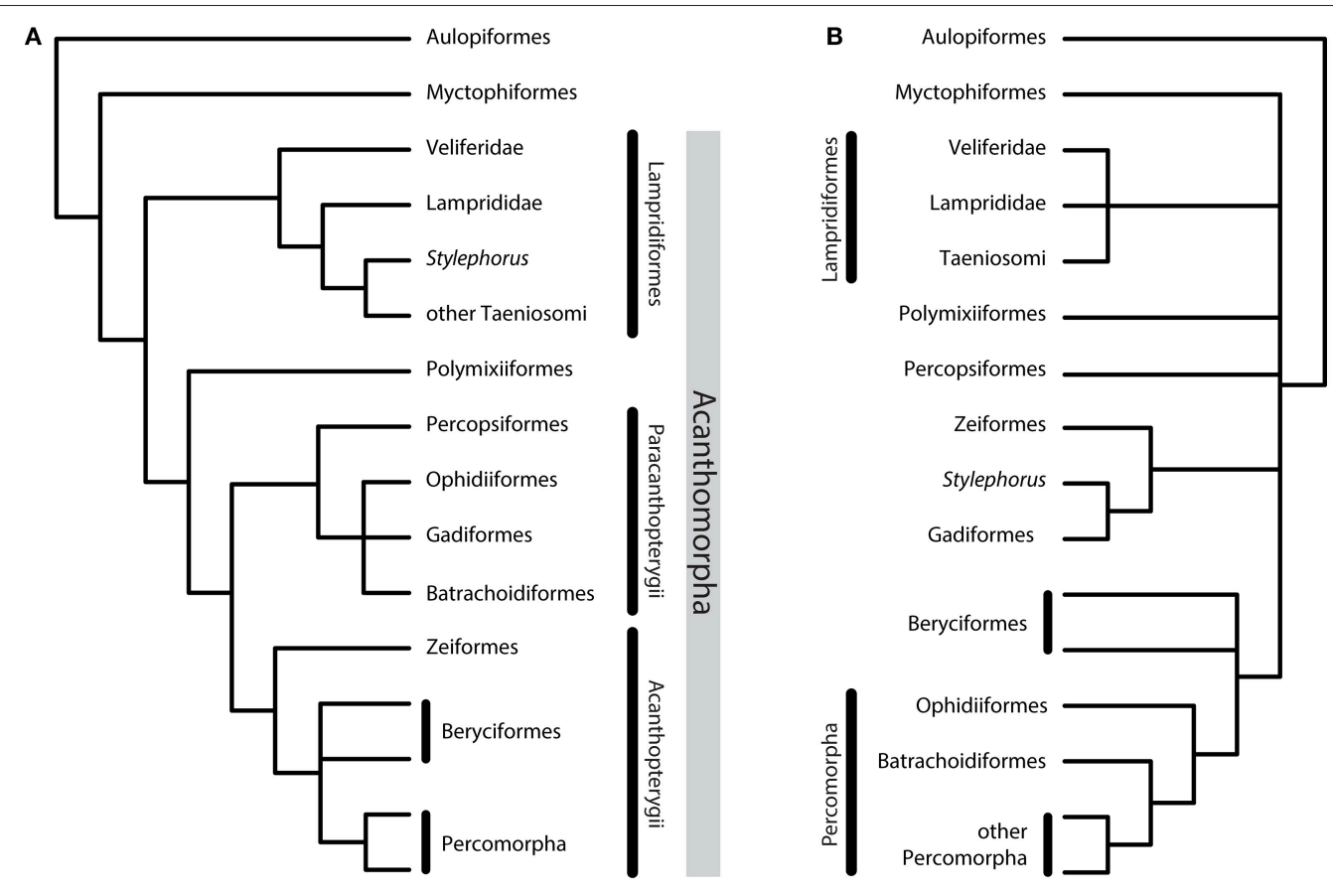

FIGURE 1 | Consensus of the phylogenetic hypotheses for Acanthomorpha, summarizing previously published results. (A) Morphological hypothesis (Patterson and Rosen, 1989; Johnson and Patterson, 1993; Olney et al., 1993). (B) Molecular hypothesis based on the latest large-scale acanthomorph datasets (Miya et al., 2005, 2007; Broughton, 2010; Betancur-R et al., 2013; Grande et al., 2013; Near et al., 2013; Chen et al., 2014).

et al., 2001, 2003, 2005, 2007; Poulsen et al., 2013), combined (Chen et al., 2003, 2014; Mirande, 2016) and nuclear (Li et al., 2008; species tree of Faircloth et al., 2013) datasets. In the latter case, Lampridiformes (opahs, oarfishes and allies; Figure 2C), at least, form a clade with Myctophiformes (the lanternfishes; Figure 2B), considered as the extant sister group to acanthomorphs on the basis of morphology (Rosen, 1973; Stiassny, 1986, 1996; Johnson, 1992). This uncertainty about acanthomorph monophyly is probably linked to the uncertainty about the position of Lampridiformes: They have been assigned to almost every possible position within the acanthomorph tree in the successive molecular studies, often associated with low support values (Davesne et al., 2014).

\section{Unresolved Position for Polymixiiformes and Percopsiformes}

Other acanthomorph groups also have a very variable position from one study to another. Polymixiiformes (represented today only by the genus Polymixia, beardfishes; Figure 2D) has been classified in Beryciformes (Greenwood et al., 1966) and possibly Paracanthopterygii (Rosen and Patterson, 1969). However, the latest anatomical studies supported Polymixiiformes as an isolated lineage (Figure 1A), sister to all other acanthomorphs except for Lampridiformes (Stiassny and Moore, 1992; Johnson and Patterson, 1993). Percopsiformes (trout-perches and allies; Figures 2E,F) has been consistently supported as part of Paracanthopterygii (see below and Figure 1A) by anatomists (Gosline, 1963; Rosen and Patterson, 1969; Patterson and Rosen,
1989; Murray and Wilson, 1999). Mitochondrial data support Percopsiformes and Polymixia as closely related to GadiformesZeiformes, either as sequential sister groups (Miya et al., 2003; Broughton, 2010), or forming a clade together (Miya et al., 2005, 2007; Dillman et al., 2011). Studies based on either nuclear markers, or a combination of nuclear and mitochondrial markers, have suggested different positions for these two taxa: Either sequential sister groups to Gadiformes-Zeiformes (Dettai and Lecointre, 2005; Grande et al., 2013; Chen et al., 2014) or to Lampridiformes ( $\mathrm{Li}$ et al., 2009), sister to Acanthopterygii for Polymixia and to Gadiformes-Zeiformes for Percopsiformes (Betancur-R et al., 2013), or forming together a clade which is in turn sister to all other acanthomorphs (Near et al., 2013; Malmstrøm et al., 2016). The phylogenetic position of these two taxa is, therefore, far from being settled on the basis of current data (Figure 1B).

\section{Composition of Paracanthopterygii}

According to its first delimitation (Greenwood et al., 1966), Paracanthopterygii was a series of teleosts sister to Acanthopterygii, and including Percopsiformes, Batrachoidiformes (toadfishes; Figure 2L), Gobiesociformes (clingfishes), Lophiiformes (anglerfishes), Gadiformes (cods, hakes and allies; Figure 2H), Ophidiiformes (cusk-eels and allies; Figure 2J), and Zoarcoidei (eelpouts).

Rosen and Patterson (1969) proposed a list of characters supporting Paracanthopterygii, which they later revised and completed (Patterson and Rosen, 1989). In their definition, Paracanthopterygii only includes Percopsiformes, 
A
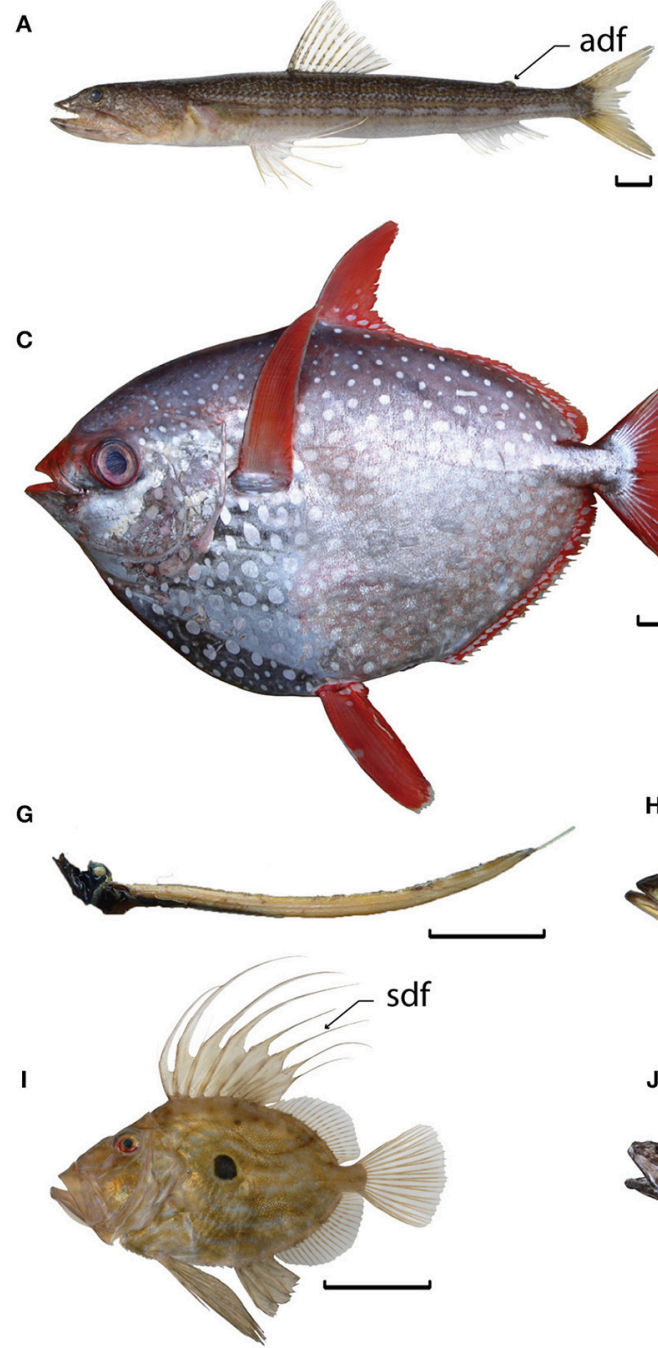

K
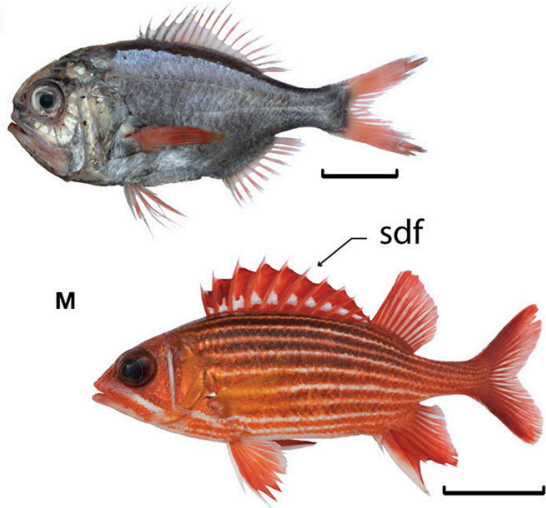

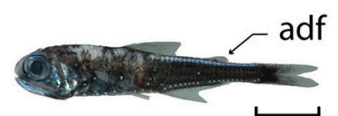

D

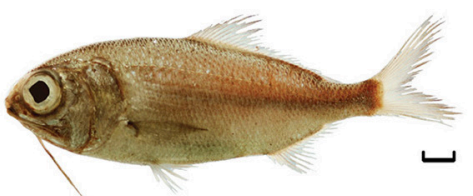

E

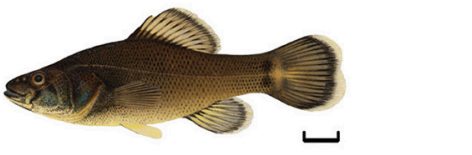

$\mathbf{F}$
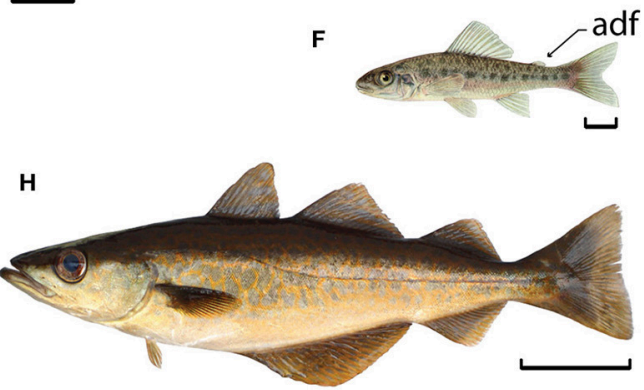

$\mathbf{J}$
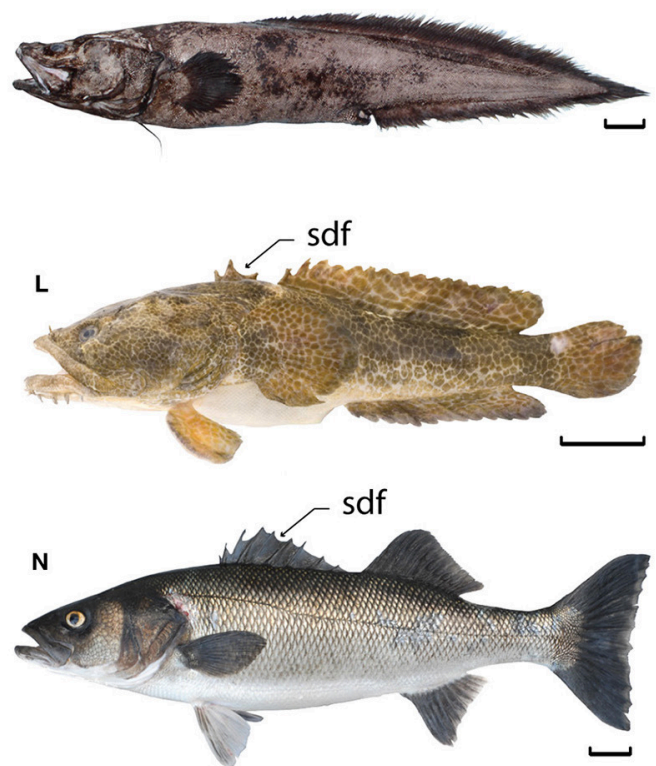

FIGURE 2 | Examples of species from the taxa studied. (A) Aulopiformes, Synodus saurus, MNHN/SBMC uncataloged. (B) Myctophiformes, Myctophum punctatum, MNHN/SBMC uncataloged. (C) Lampridiformes, Lampris guttatus, SBMC 2004-0006. (D) Polymixiiformes, Polymixia lowei, NOAA uncataloged. (E) Percopsiformes, Aphredoderus sayanus, painting. (F) Percopsiformes, Percopsis omiscomaycus, painting. (G) Stylephoriformes, Stylephorus chordatus, MNHN.IC.2004-1316. (H) Gadiformes, Pollachius pollachius, MNHN/SBMC uncataloged. (I) Zeiformes, Zeus faber, MNHN/SBMC uncataloged. (J) Ophidiiformes, Cataetyx laticeps, MNHN/SBMC uncataloged. (K) Beryciformes, Hoplostethus mediterraneus, MNHN/SBMC uncataloged. (L) Batrachoidiformes, Halobatrachus didactylus, MNHN/SBMC uncataloged. (M) Beryciformes, Sargocentron hastatum, MNHN 2013-0848. (N) Percomorpha, Dicentrarchus labrax, MNHN/SBMC uncataloged. Abbreviations: adf, adipose fin; sdf, spinous first dorsal fin. Scale bar equals $10 \mathrm{~mm}$ (A,B, D-F), $50 \mathrm{~mm}$ (G-N), $100 \mathrm{~mm}$ (C). Sizes are based on specimen measurements, or on the "common length" measure given in FishBase (D-F). Photos D. Davesne (G), courtesy of Iglésias (2014) (A,B, H-N), NOAA (D) and Wikimedia Commons (D,E). 
Batrachoidiformes, Lophiiformes, Gadiformes, and Ophidiiformes (Figure 1A). This assemblage has been controversial since its inception, and most of its constituent taxa have been excluded from it at one point or another on the basis of their anatomy (Gosline, 1968; Fraser, 1972; Gill, 1996; Chanet et al., 2013; Grande et al., 2013). Moreover, molecular data have consistently shown the polyphyly of Paracanthopterygii sensu Patterson and Rosen (see below for details), implying that the delimitation of the group should be comprehensively reassessed.

\section{Gadiformes-Zeiformes Clade}

Gadiformes have always been part of Paracanthopterygii since the first definition of the group (Greenwood et al., 1966; Rosen and Patterson, 1969; Patterson and Rosen, 1989). Zeiformes (dories; Figure 2I) were considered as close relatives of Tetraodontiformes (triggerfishes, pufferfishes, and allies) and Caproidae (boarfishes) in the first detailed study of their position amongst acanthomorphs (Rosen, 1984). Later on, studies including a larger sampling of acanthomorph representatives suggested that Zeiformes lies within Acanthopterygii, but outside Percomorpha (Stiassny and Moore, 1992; Johnson and Patterson, 1993). Subsequent analyses (Tyler et al., 2003; Tyler and Santini, 2005) provided arguments for the monophyly and intrarelationships of Zeiformes, while once again proposing a clade that unites them with Tetraodontiformes and Caproidae.

Since their earliest attempts at resolving acanthomorph phylogeny, studies based on molecular datasets have suggested a very different position for both orders (Figure 1B) by supporting a Gadiformes-Zeiformes clade (Wiley et al., 2000; Miya et al., 2001, 2003; Chen et al., 2003; Dettai and Lecointre, 2004, 2005). The subsequent molecular studies have also consistently supported this clade (Li et al., 2009; Near et al., 2012, 2013; Betancur-R et al., 2013; Grande et al., 2013; Chen et al., 2014; Malmstrøm et al., 2016).

Despite some early claims (Wiley et al., 2000), this grouping (or, at least, an inclusion of Zeiformes within Paracanthopterygii) had already been anticipated by some morphologists (Gaudant, 1979; Gayet, 1980a,b; Gill, 1996). This hypothesis seems to indeed be supported by numerous morphological characters (Borden et al., 2013; Grande et al., 2013), but has never been formally tested by a comprehensive morphological phylogenetic analysis.

\section{Stylephorus Outside Lampridiformes}

Stylephorus chordatus (the tube-eye; Figure 2G) is a distinctive mesopelagic acanthomorph with an elongate body, a reduced caudal fin, and extremely modified jaws forming a protrusible tube-like feeding device. Several interpretations have prevailed regarding the position of Stylephorus_including possible affinities with "amphibians" rather than with teleosts according to its original describer in 1791 (Pietsch, 1978)-but once the discovery of more specimens allowed for further investigations on its morphology, it was included in Lampridiformes (Regan, 1908, 1924; Starks, 1908). Stylephorus was classified within the lampridiform suborder Taeniosomi (Figure 1A), alongside Radiicephalus, Lophotidae, Trachipteridae, and Regalecidae in subsequent works (Oelschläger, 1983; Olney, 1984; Olney et al., 1993).
The first molecular (mitogenomic) phylogenetic analysis that includes this species (Miya et al., 2007) proposed a different position for Stylephorus, within the Gadiformes-Zeiformes clade (Figure 1B). This result has been corroborated subsequently in every other analysis of mitochondrial and nuclear markers (Near et al., 2012, 2013; Betancur-R et al., 2013; Grande et al., 2013; Malmstrøm et al., 2016), and by the shared loss of the immune system's $M x$ gene (Solbakken et al., 2016). This new arrangement has also been supported (Grande et al., 2013) and opposed (Roberts, 2012) on the basis of morphology, each time without a comprehensive phylogenetic analysis.

\section{The Status of Beryciformes}

Beryciformes has been variably interpreted over time. Initially, it was viewed as a paraphyletic assemblage of acanthopterygians (Patterson, 1964; Greenwood et al., 1966). Later studies (Johnson and Patterson, 1993; Patterson, 1993) have supported a monophyletic Beryciformes that includes Berycidae (alfonsinos), Trachichthyidae (roughies; Figure 2K), Holocentridae (soldierfishes and squirrelfishes; Figure 2M), and other related families. Stephanoberyciformes (deep sea taxa such as ridgeheads, whalefishes, and pricklefishes) was regarded as either an independent order (Johnson and Patterson, 1993), or included in Beryciformes (Moore, 1993). In these studies, Beryciformes was seen as the sister group to percomorphs within Acanthopterygii (Figure 1A). At least one anatomical study, using characters of the pelvic girdle, challenged the monophyly of Beryciformes by recovering holocentrids as closer to percomorphs than to other beryciforms (Stiassny and Moore, 1992).

Molecular studies have supported diverse arrangements for Beryciformes (Figure 1B). They have been resolved as monophyletic, either excluding (Wiley et al., 2000) or including Stephanoberyciformes (Miya et al., 2001, 2005; Near et al., 2012, 2013; Grande et al., 2013), or as paraphyletic (Colgan et al., 2000; Li et al., 2009; Betancur-R et al., 2013; Chen et al., 2014).

\section{Ophidiiformes and Batrachoidiformes in Percomorpha}

The inclusion of Ophidiiformes and Batrachoidiformes in Paracanthopterygii is consistently rejected by molecular studies (Wiley et al., 2000; Miya et al., 2003, 2005; Li et al., 2009; Near et al., 2012, 2013; Betancur-R et al., 2013; Chen et al., 2014). According to these studies, they are included in Percomorpha, as successive sister groups to all other percomorphs (Figure 1B). The same studies consistently group Lophiiformes with Tetraodontiformes instead of Batrachoidiformes (Miya et al., 2003; Dettai and Lecointre, 2005; Yamanoue et al., 2007; Holcroft and Wiley, 2008; Betancur-R et al., 2013; Near et al., 2013), and at least some anatomical data also support this hypothesis (Chanet et al., 2012, 2013).

\section{Aims of the Study}

Within the new phylogenetic framework brought by molecular studies, it is time to revisit the large-scale acanthomorph intrarelationships with morphological data, to address the following issues: (1) are the morphological data adequate to 
robustly resolve deep phylogenetic divergences; (2) are the topologies supported by these data congruent with previous hypotheses supported by morphological (Figure 1A), molecular data (Figure 1B) or neither; (3) do fossil taxa have an impact on the topology?

The sampling we use allows testing all previous phylogenetic hypotheses, morphological as well as molecular. This was not the case of the previous studies based on morphology, which used a reduced subset of acanthomorph diversity, not including some key taxa. For example, Gadiformes, Batrachoidiformes, and Ophidiiformes were all absent from the matrix of Johnson and Patterson (1993). Our sampling also includes fossil taxa from the Late Cretaceous; that is, amongst the oldest known acanthomorphs. They are expected to display character state combinations that are absent in extant taxa. A number of previous studies have stressed the importance of fossil taxa for phylogenetic inference (Gauthier et al., 1988; Donoghue et al., 1989; Cobbett et al., 2007), including in acanthomorphs (Santini and Tyler, 2004; Davesne et al., 2014). The experimental design of the present study permits us to estimate the influence of fossils on the results by analyzing the dataset with and without them.

\section{MATERIALS AND METHODS}

\section{Taxon Sampling}

Our taxon sample includes 26 taxa, of which 19 are extant.

Synodus and Gymnoscopelus represent Aulopiformes (lizardfishes; Figure 2A) and Myctophiformes (lanternfishes; Figure 2B), respectively. Together, they represent two of the closest extant acanthomorph relatives, according to the morphological (Rosen, 1985; Stiassny, 1986, 1996; Johnson and Patterson, 1993) and most molecular evidence (Broughton, 2010; Near et al., 2012, 2013; Betancur-R et al., 2013; Grande et al., 2013). The inclusion of a myctophiform in the analysis allows testing the alternative hypothesis of acanthomorph polyphyly (see above).

Our sampling of extant acanthomorphs includes at least one representative for each of the groupings identified by both molecular and morphological data (Figure 1). Thus, the minimal taxonomic coverage that is needed to test the various topologies found in the literature is included. Its focus is on the main relationships between acanthomorph clades and some portions of the acanthomorph tree are not covered enough to resolve their relationships (e.g., percomorphs). Further, more detailed studies would be needed to address these other phylogenetic questions.

Velifer, Lampris, and Regalecus represent Lampridiformes; and Stylephorus has been included, in order to test its position among Lampridiformes or other acanthomorphs. Polymixia represents Polymixiiformes. Aphredoderus and Percopsis (for Percopsiformes), Merluccius and Bregmaceros (for Gadiformes), Halobatrachus (for Batrachoidiformes) and Brotula (for Ophidiiformes) allow testing the composition of the Paracanthopterygii, as defined by Patterson and Rosen (1989). We did not include Lophiiformes, because all molecular data and some anatomical evidence suggest a deeply nested position within Percomorpha. Zeus and Cyttus are added in order to test the proposed Gadiformes+Zeiformes relationship.
A trachichthyid (Hoplostethus) and a holocentrid (Sargocentron) represent Beryciformes sensu lato. The inclusion of these both families leaves open the possibility of recovering a paraphyletic Beryciformes, as suggested by some studies (Stiassny and Moore, 1992; Betancur-R et al., 2013). Dicentrarchus and Lates represent 'generalized' representatives of Percomorpha, which do not show extreme morphological specializations that could hinder phylogenetic reconstruction.

The seven fossil taxa (Figure 3) have been chosen for their potential phylogenetic positions (as suggested by previous studies) that span the entire tree. †Ctenothrissa, from the Cenomanian (Late Cretaceous) of England and Lebanon (Figure 3A), was described as either a stem-acanthomorph (Patterson, 1964) or a stem-ctenosquamate (Gaudant, 1978, 1979). The affinities of $\uparrow P y$ cnosteroides, from the Cenomanian of Hajula, Lebanon (Figure 3C), have been interpreted differently depending on the authors, owing to its singular character state combination. According to previous phylogenetic analyses, $\dagger$ Pycnosteroides is a member of Lampridomorpha (Davesne et al., 2014; Delbarre et al., 2016), alongside with †“Aipichthys” (Figure 3B) and $†$ Aipichthyoides (both from the Cenomanian of Near East and England). In the present study, the character coding for †"Aipichthys" was based on the species † $†$." minor and $\dagger$ " $A$." velifer, which are phylogenetically distinct from $\dagger A$. pretiosus, the type species of the genus (Delbarre et al., 2016). †Sphenocephalus, from the Campanian (Upper Cretaceous) of Germany, (Figure 3D) has been described as a paracanthopterygian, closely related to at least Percopsiformes and Gadiformes (Rosen and Patterson, 1969; Patterson and Rosen, 1989; Murray and Wilson, 1999; Grande et al., 2013; Davesne et al., 2014). †Omosomopsis, from the Cenomanian of Jbel Tselfat, Morocco (Figure 3E), has been interpreted as a polymixiiform (Patterson, 1993; Taverne, 2011), but some of its characters suggest a close relationship to paracanthopterygians (Otero and Gayet, 1996). †Stichocentrus, from the Cenomanian of Hajula, Lebanon (Figure 3F), is a probable beryciform that has been regarded as related to modern holocentrids (Gayet, 1980c, 1982). It has been chosen amongst numerous other, closely related coeval taxa, because it has been welldescribed morphologically (Patterson, 1967; Gayet, 1980c) and proposed as a fossil calibration point for divergence-time analyses of acanthomorph phylogeny (Benton et al., 2015). All the fossils in our sampling come from Late Cretaceous deposits, more specifically from the Cenomanian (with the exception of $\uparrow$ Sphenocephalus, found exclusively in Campanian deposits). In consequence, they are coeval with the oldest known acanthomorph body fossils (Patterson, 1993).

\section{Character Coding}

The morphological characters were observed on dissections and dry osteological preparations, or on fluid-preserved specimens housed in public collections (Appendix 1 in Supplementary Material). When preserved in fluid, the specimens were X-ray tomographed (GE Phoenix v-tome-x L240, microfocus $240 \mathrm{kV}$ at the AST-RX platform, Muséum national d'Histoire naturelle, Paris) and the skeleton was virtually reconstructed in $3 \mathrm{D}$ by means of the Mimics software (version 17.0 64-bit). The list 

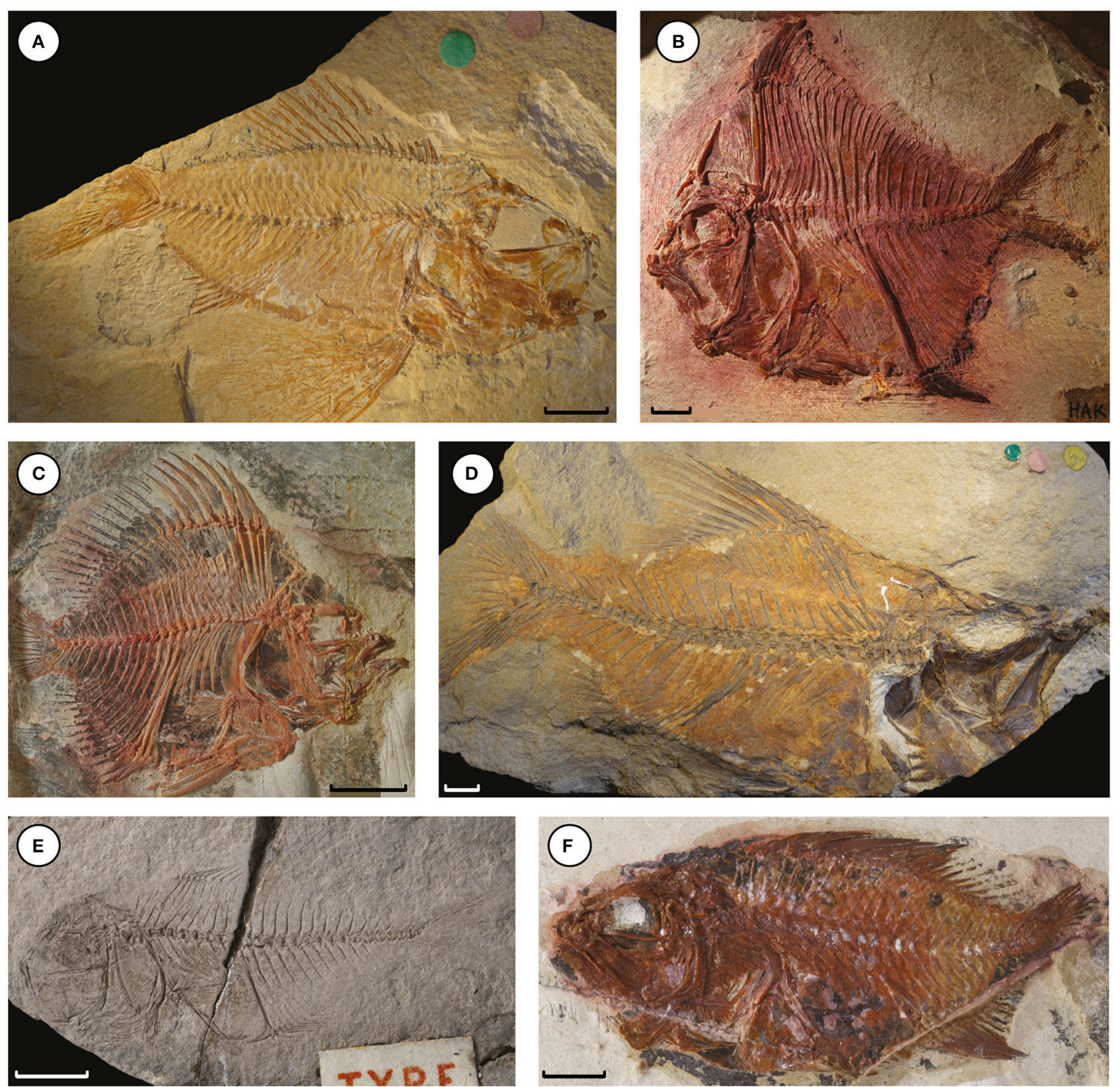

FIGURE 3 | Six of the seven fossil taxa used in the analyses. (A) †Ctenothrissa signifer, NHMUK PV P47524. (B) †'Aipichthys' velifer, MNHN.F.HAK57. (C) $\uparrow$ Pycnosteroides levispinosus, MNHN.F.HDJ105. (D) †Sphenocephalus fissicaudus, NHMUK PV P9059. (E) †Omosomopsis simum, MNHN.F.DTS222d. (F) $\dagger$ †tichocentrus liratus, MNHN.F.HDJ97. Scale bar equals $10 \mathrm{~mm}$ (A-D, F), $5 \mathrm{~mm}$ (E). Photos by D. Davesne, C. Lemzaouda, and P. Loubry.

of specimens used in the study is provided in Appendix 1 of Supplementary Material. We coded the remaining taxa by using data from the literature (e.g., Świdnicki, 1991; Otero, 2004).

The morphological characters that we use for our phylogenetic analyses (Appendix 2 in Supplementary Material) are mostly compiled from previous studies (Stiassny, 1986; Patterson and Rosen, 1989; Stiassny and Moore, 1992; Johnson and Patterson, 1993; Otero and Gayet, 1996; Grande et al., 2013). Almost all characters are coded from the skeleton. The resulting data matrix (Supplementary Table 1) contains 26 taxa and 66 characters. It is available in electronical version on MorphoBank (O'Leary and Kaufman, 2011, 2012), project 2349 (http://morphobank.org/permalink/?P2349). There is $7.58 \%$ of missing data, noted as "?" in the matrix. Most of them are due to incomplete preservation of fossil taxa. $5.24 \%$ of the character states are scored as inapplicable. They are noted as "-" in the matrix and are mainly a consequence of the coding strategy used for characters 2-3, 31-32, 35-36, and $65-66$. Character 24 is the only one to be parsimonyuninformative. 


\section{Phylogenetic Analyses}

We performed three phylogenetic analyses. Analysis 1 is a simultaneous analysis of all 26 taxa of our sampling, Analysis 2 includes the 19 extant taxa only, and Analysis 3 includes the seven fossil taxa only. Analysis 2 and Analysis 3 allow us to estimate the impact of fossil taxa on the results. Character polarity was determined by the outgroup criterion. Trees were rooted with the aulopiform Synodus in Analyses 1 and 2, because every morphological and molecular study to date has recovered Aulopiformes outside of Acanthomorpha. The trees were rooted with $†$ Ctenothrissa (as the only fossil taxon in our dataset that is not a crown-acanthomorph) in the third analysis. In all analyses, every character was treated as unordered. The character matrix was submitted to parsimony analyses using both PAUP* version 4.0a147 (Swofford, 2002) and TNT version 1.1 (Goloboff et al., 2008). With PAUP*, we performed a heuristic search with a random addition sequence and the "TBR" branch-swapping algorithm (10000 replicates, holding 10 trees at each step). With TNT we performed a new technology search with the default parameters for sectorial search, ratchet (10 iterations), drift (10 cycles) and tree-fusing, and hitting minimal tree length 100 times. We also used TNT to run 1000 replicates of a bootstrap analysis retaining all clades found with a frequency $\geq 50 \%$, and to estimate the Bremer support values.

\section{RESULTS}

The results of all analyses are identical whether PAUP* or TNT is used. The simultaneous analysis of the extant and fossil taxa (Analysis 1) yielded one parsimonious tree, with a length of 198 steps, a consistency index (CI) of 0.419 and a retention index (RI) of 0.684 (Figure 4). The consistency and retention indexes of each character after this analysis are presented in the Supplementary Table 2 .

The tree shows †Ctenothrissa as a sister to Acanthomorpha, which include three main clades: (1) a clade Lampridomorpha (sensu Davesne et al., 2014) including †"Aipichthys," $\dagger$ Aipichthyoides, Velifer, Lampris and Regalecus, but not $†$ Pycnosteroides; (2) a clade ("Clade A") that includes beryciforms in paraphyly with Percomorpha (sensu Wiley and Johnson, 2010; Betancur-R et al., 2014) which, in turn, includes Dicentrarchus and Lates as sequential sister groups to Batrachoidiformes (Halobatrachus) and Ophidiiformes (Brotula); (3) a clade ("Clade B”) that includes $†$ Pycnosteroides, Polymixia, †Omosomopsis, $\dagger$ Sphenocephalus, and Percopsiformes as sequential sister groups to a clade that unites Gadiformes, Zeiformes, and Stylephorus. Lampridomorpha is sister to all remaining acanthomorphs.

Analysis 2 (extant taxa only) yielded four parsimonious trees with a length of 166 steps, a CI of 0.482 and a RI of 0.676 (Figure 5A). It shows a largely incongruent topology: Polymixia and Percopsiformes are sister groups to the other acanthomorphs, including the Clade A of Analysis 1 in paraphyly with Zeiformes, Gadiformes and "traditional" Lampridiformes (including Stylephorus).

Analysis 3 (fossil taxa only) yielded one parsimonious tree with a length of 43 steps, a CI of 0.791 and a RI of
0.609 (Figure 5B). The topology is entirely compatible with that of Analysis 1, with $†$ Pycnosteroides, $†$ Omosomopsis, and $\dagger$ Sphenocephalus grouped together and forming a clade with $\dagger$ Stichocentrus, while †'Aipichthys' and †Aipichthyoides form another clade.

The relatively low trees' retention indexes, bootstrap values and Bremer supports for most clades (Figures 4, 5) reflect the relatively high level of homoplasy in the dataset. For instance, in Analysis 1 only 15 characters (23\% of the total) have a RI of 1.000 , representing uniquely derived characters (Supplementary Table 2).

\section{DISCUSSION}

\section{Acanthomorph Intrarelationships}

The three main clades recovered by Analysis 1 have been given various names in different classifications, even when their taxonomic content is essentially the same (Johnson and Patterson, 1993; Wiley and Johnson, 2010; Betancur-R et al., 2014; Nelson et al., 2016). In order to maintain clarity in the discussion, we give the following provisional names to these clades:

- Lampridomorpha: Lampridiformes and their extinct close relatives (sensu Davesne et al., 2014);

- Clade A: "Beryciformes" and Percomorpha (including Ophidiiformes and Batrachoidiformes). This clade is either named Euacanthopterygii (Johnson and Patterson, 1993), Acanthopterygii (Nelson et al., 2016), or Euacanthomorphacea (Betancur-R et al., 2014);

- Clade B: Polymixiiformes, Percopsiformes, Gadiformes, Zeiformes, Stylephorus, and their extinct close relatives. This assemblage is alternatively named Paracanthopterygii (Grande et al., 2013; Nelson et al., 2016) or Paracanthomorphacea (Betancur-R et al., 2013, 2014).

These three clades are unambiguously recovered by our Analysis 1 , but the support values of Clades A and B are relatively low (Figure 4). Further anatomical work (including on "soft" tissues) on character distribution and homology would be needed in order to find supplementary synapomorphies for the clades recovered by this study. Adding more representative taxa for each acanthomorph group could also prove valuable to increase the support of these deep relationships.

\section{Acanthomorph Monophyly}

We recovered the clade Acanthomorpha in the two analyses that tested its monophyly (Figures 4, 5A). With Analysis 1 , Acanthomorpha is supported by three unambiguous synapomorphies: The presence of unpaired and unsegmented spines (Figures 6A,B) on the dorsal $\left(35^{1}\right)$ and anal fins $\left(40^{1}\right)$, and the contact between the lateral ethmoids and the vomer $\left(8^{1}\right.$; Figure 6C). All three characters were previously used to define Acanthomorpha (Stiassny, 1986; Johnson and Patterson, 1993).

$\dagger$ Ctenothrissa is recovered as sister to crown-acanthomorphs, in a position that somehow reflects Patterson's (1964) ideas but contradicts later studies (Gaudant, 1978, 1979; Davesne et al., 2014). This topology, while well-supported by our data, 


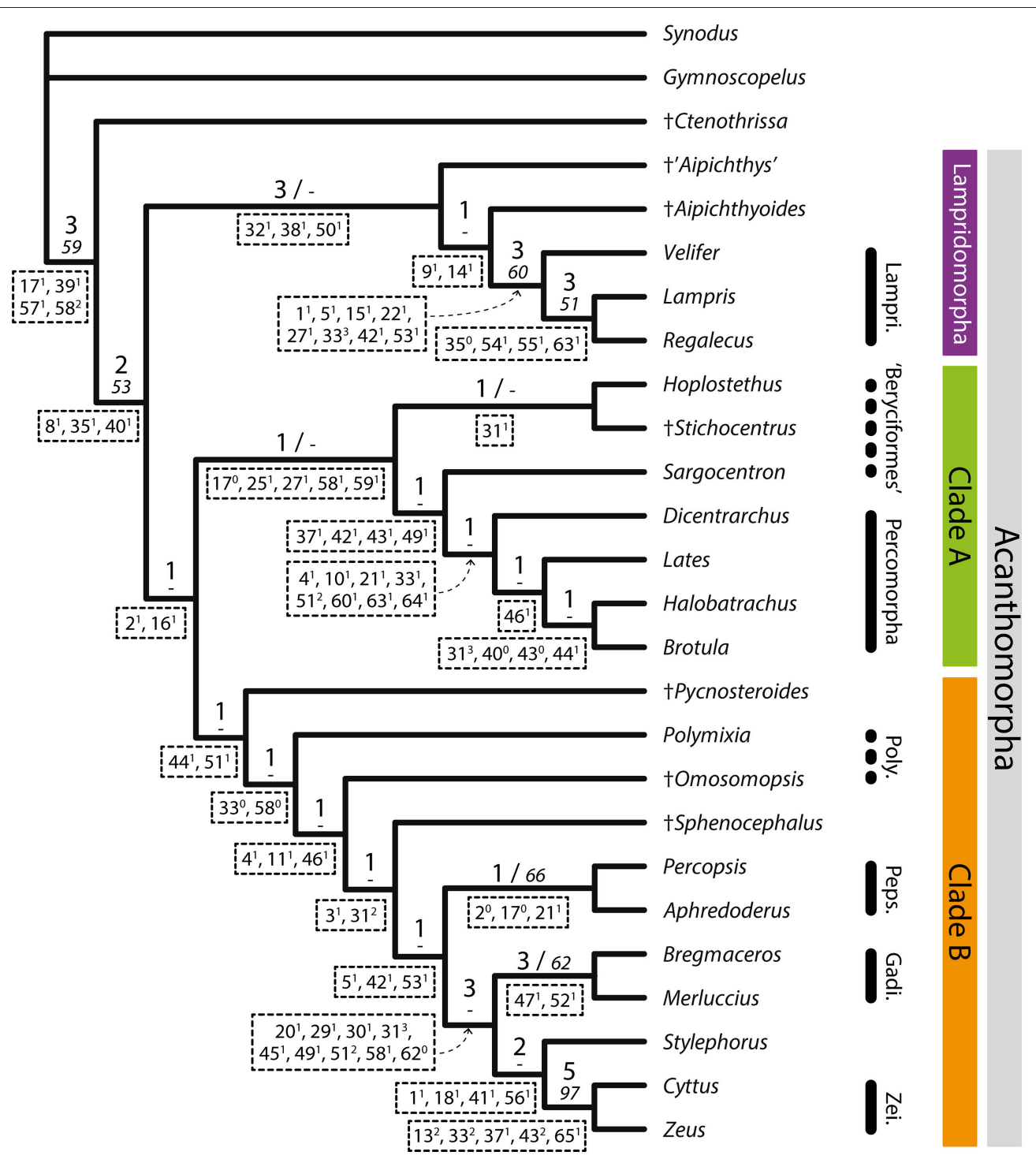

FIGURE 4 | Parsimonious tree obtained from Analysis 1 (complete analysis, extant and fossil taxa). Length = 198, $\mathrm{Cl}=0.419$, RI = 0.684. Support values are above branches: Bremer indexes (bigger font)/bootstrap values (italics). Unambiguous synapomorphies are below branches.

should be taken with caution, since the sampling of nonacanthomorph taxa is too limited to ensure a definitive placement of $†$ Ctenothrissa. The four unambiguous synapomorphies of this + Ctenothrissa + Acanthomorpha clade also characterize acanthomorphs if fossils are not taken into account:

- The loss of the adipose fin $\left(39^{1}\right)$, implying the independent re-acquisition of this attribute in modern Percopsiformes (Figure 2F);

- The anterior position of the pelvic girdle $\left(57^{1}\right)$. A "trend" toward an anterior migration of the pelvic fin in acanthomorphs was already described by Greenwood et al. (1966), and later more in details by Stiassny and Moore (1992) and Parenti and Song (1996). More specifically, it is redefined here as the pelvic girdle inserting anterior to the ventral tip of the distal postcleithrum (Figure 6B);

- Two characters that have been previously optimized as synapomorphies of Lampridomorpha (Davesne et al., 2014): The pelvic girdle contacts the pectoral girdle at the level of the coracoids $\left(58^{2}\right)$, and the hyomandibula bears only one articular head with the cranium $\left(17^{1}\right)$ - both of these characters undergo numerous reversions within Acanthomorpha.

Finally, two synapomorphies are ambiguous for Acanthomorpha because there is no data regarding their presence in $\dagger$ Ctenothrissa. Nonetheless, they are unique to acanthomorphs if only extant taxa are considered. These are the close bonding between the dorsal limb of the posttemporal and the epioccipital $\left(13^{1}\right)$ and the presence of facets on the first vertebral centrum for 

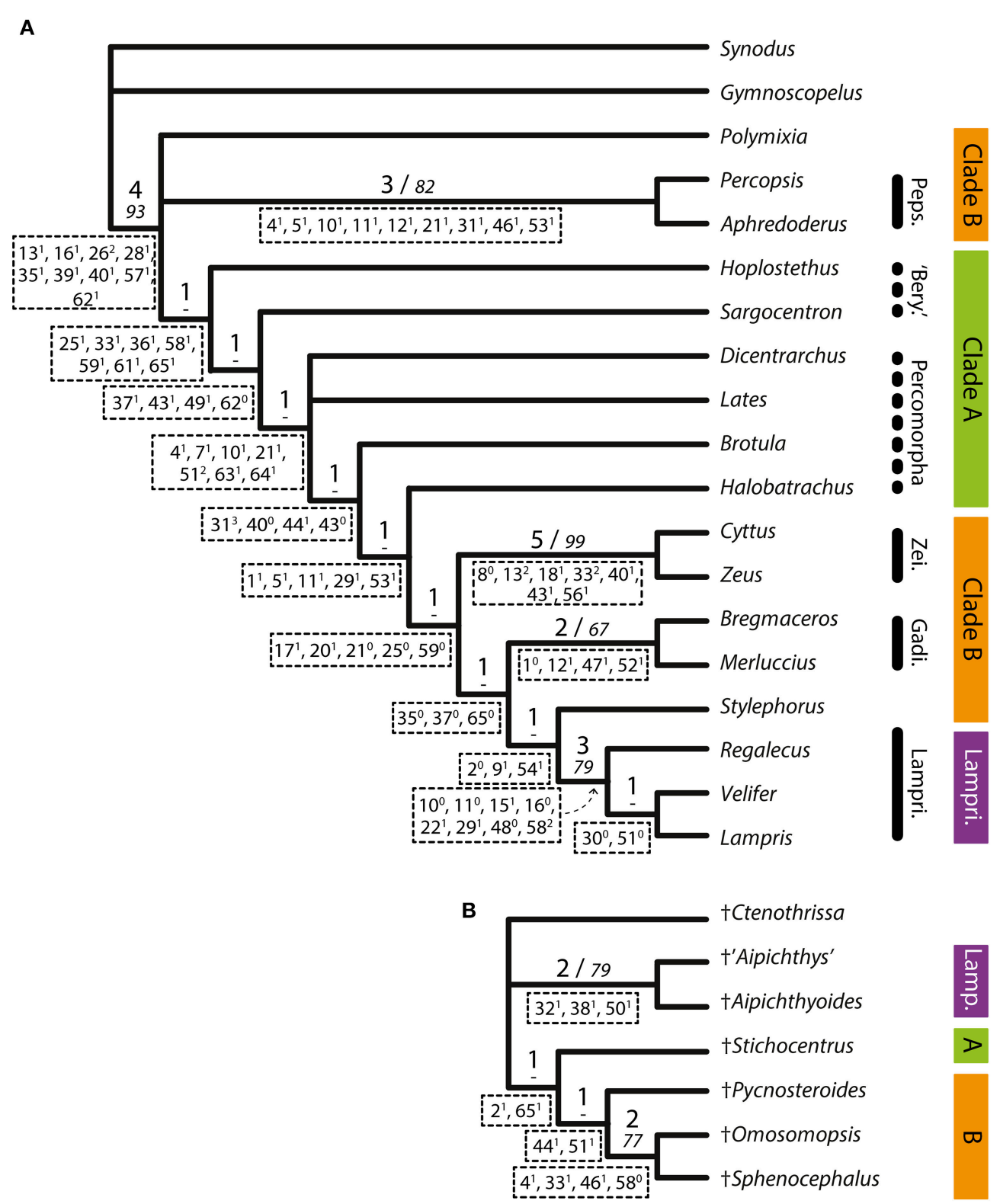

FIGURE 5 | (A) Strict consensus of the four parsimonious trees obtained from Analysis 2 (extant taxa only). Length = 166, Cl = 0.482, RI = 0.676. (B) Tree obtained from Analysis 3 (fossil taxa only). Length $=43, \mathrm{Cl}=0.791, \mathrm{Rl}=0.609$. The clade names on the right refer to the results of Analysis 1 (Figure 4). Support values are above branches: Bremer indexes (bigger font)/bootstrap values (italics). Unambiguous synapomorphies are below branches.

its articulation with exoccipital condyles $\left(28^{1}\right)$. Both characters were already regarded as acanthomorph synapomorphies (Rosen, 1985; Stiassny, 1986).

With these nine synapomorphies in total, our study strongly supports the monophyly of Acanthomorpha, in accordance with earlier anatomical works (Stiassny and Moore, 1992; Johnson and Patterson, 1993; Davesne et al., 2014) and with most molecular studies based on nuclear markers (Betancur-R et al., 2013; Faircloth et al., 2013; Near et al., 2013) and in contradistinction to most of the molecular studies using part or all of the mitogenome (Miya et al., 2003, 2005; Chen et al., 2014; Mirande, 2016).

\section{Position of Lampridiformes}

Analysis 1 recovered Lampridomorpha (with lampridiforms as its only extant members) as the sister group to all other acanthomorphs (Clade A + Clade B). This topology is usually recovered by morphology (Johnson and Patterson, 1993; Davesne et al., 2014) but is poorly supported by molecular data, both within datasets (associated support values are often low) and from one study to another. This suggests that incongruence in the phylogenetic positions of Lampridiformes might be driven by sampling or branch-length artifacts rather than by a strong phylogenetic support. 

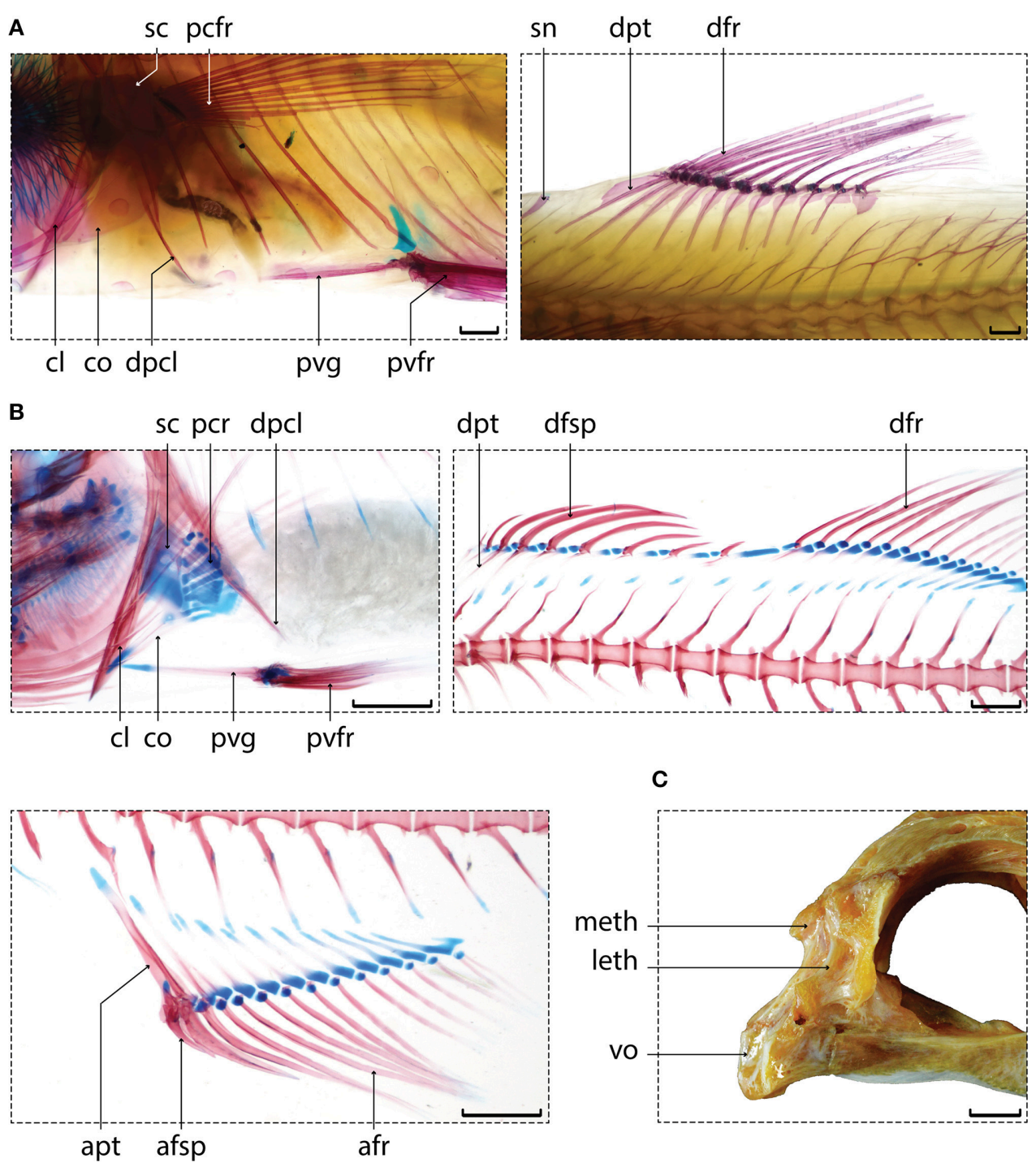

FIGURE 6 | Examples of acanthomorph synapomorphies. (A) Relative positions of the pelvic and pectoral girdle (left), and dorsal fin (right) of a non-acanthomorph, Myctophum nidulum, MNHN.IC.1993.2333. (B) Relative positions of the pelvic and pectoral girdle (left), dorsal fins (right), and anal fin (below) of an acanthomorph, Dicentrarchus labrax, MNHN uncataloged. (C) Ethmoid region of an acanthomorph, Sparus aurata, MNHN uncataloged. Abbreviations: afr, anal-fin soft rays; afsp, anal-fin spines; apt, anal pterygiophore; cl, cleithrum; co, coracoid; dfr, dorsal-fin soft rays; dfsp, dorsal-fin spines; dpcl, distal postcleithrum; dpt, dorsal pterygiophores; leth, lateral ethmoid; meth, mesethmoid; pcfr, pectoral-fin rays; pcr, pectoral radials; pvg, pelvic girdle; pvfr, pelvic-fin rays; sc, scapula; sn, supraneurals; vo, vomer. Scale bar equals $1 \mathrm{~mm}(\mathbf{A}, \mathbf{B}), 10 \mathrm{~mm}$ (C). C\&S preparations N. K. Schnell. Photos D. Davesne and N. K. Schnell.

In the present study, two synapomorphies unambiguously support the monophyly of (Clade A + Clade B):

- The premaxilla bears a postmaxillary process $\left(2^{1}\right)$, which is absent in lampridomorphs and non-acanthomorphs (Figure 7A);

- The supraoccipital bears a spina occipitalis $\left(16^{1}\right)$ that separates exoccipitals medially and reaches the dorsal roof of the foramen magnum. The spina occipitalis is absent in all modern Lampridiformes, while the state is unknown in fossil lampridomorphs.

\section{Position and Status of Polymixiiformes}

According to Analysis 1, Polymixia is included in Clade B, sister to the clade formed by Percopsiformes, Gadiformes, Stylephorus, and Zeiformes, echoing the molecular analyses that include mitochondrial data (Miya et al., 2003, 2005; Broughton, 2010; Chen et al., 2014). Clade B also includes the fossil taxa $\dagger$ Omosomopsis and $†$ Pycnosteroides (Figure 4).

The interpretation of $\dagger$ Pycnosteroides varies considerably between authors. It has been referred to as a member of Beryciformes (Patterson, 1964; Gayet, 1980c), Polymixiiformes (Taverne, 2011; Murray and Wilson, 2014), Acanthomorpha 
A

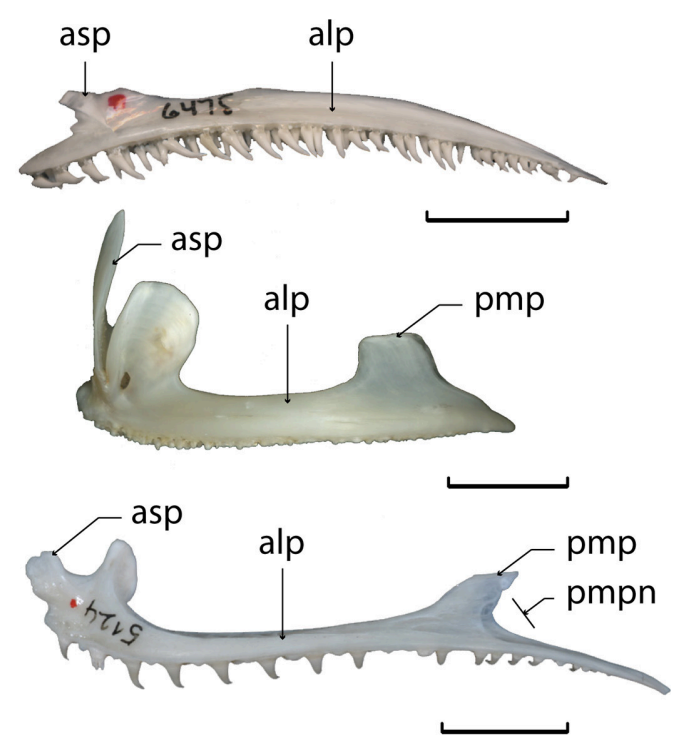

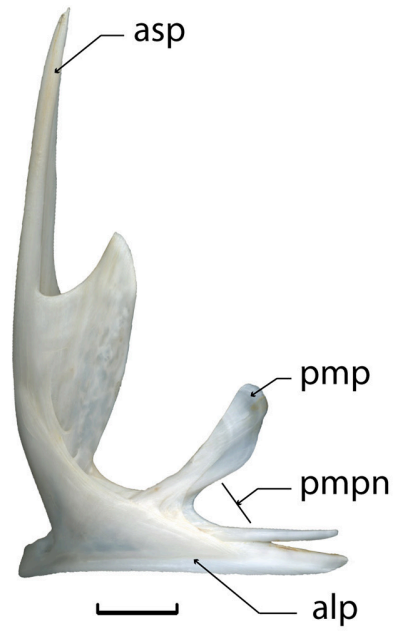

B

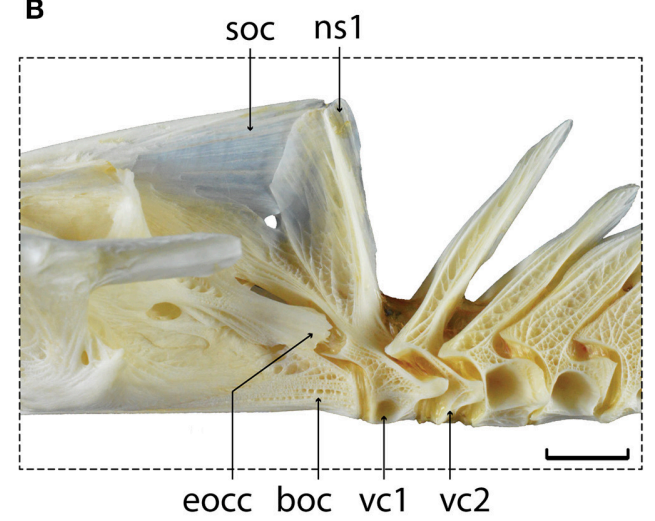

ptt soc ns1

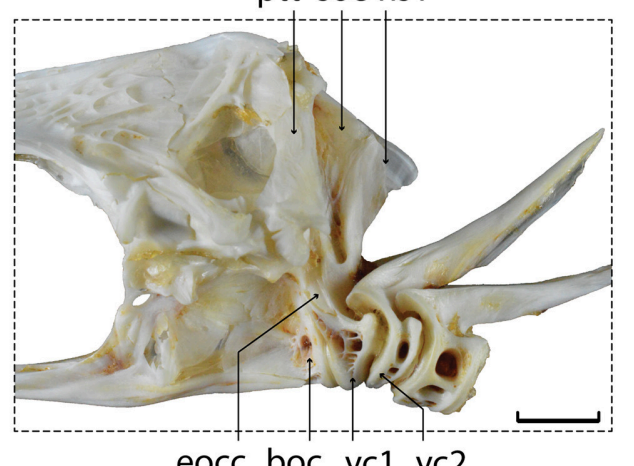

eocc boc vc1 vc2

FIGURE 7 | Examples of synapomorphies for Gadiformes + Zeiformes. (A) Left premaxillae in lateral view of (from top to bottom and left to right) Synodus scituliceps, PB-6475; Dicentrarchus labrax, MNHN uncataloged; Merluccius gayi, PB-5124; Zeus faber, MNHN uncataloged. (B) Posterior region of the neurocranium and anteriormost vertebrae in lateral view of Merluccius merluccius, MNHN uncataloged; Zeus faber, MNHN uncataloged. Abbreviations: alp, alveolar process of the premaxilla; asp, ascending process of the premaxilla; boc, basioccipital; eocc, exoccipital condyle; ns1, neural spine of the first vertebra; pmp, postmaxillary process of the premaxilla; pmpn, posterior notch on the postmaxillary process of the premaxilla; ptt, posttemporal; soc, supraoccipital; vc, vertebral centrum. Scale bar equals $10 \mathrm{~mm}$. Photos D. Davesne and Osteobase (http://osteobase.mnhn.fr/).

incertae sedis possibly related to Acanthopterygii (Patterson, 1993) and Lampridomorpha (Davesne et al., 2014; Delbarre et al., 2016). The present study contradicts all previous results by showing $\uparrow$ Pycnosteroides as the sister to modern representatives of Clade B, this being supported by two unambiguous synapomorphies: The long neural spine of the second preural vertebra $\left(44^{1}\right)$ and the reduction of the number of principal caudal-fin rays to $18\left(51^{1}\right)$.

†Omosomopsis has been presented as a member of Polymixiiformes and Polymixiidae by Patterson (1993) based on its modified anterior branchiostegals $\left(23^{1}\right)$. On the contrary, our analysis suggests that this character state might be convergent between these two taxa. Indeed, †Omosomopsis is found to be more closely related to
Percopsiformes than to Polymixia, as in the analysis by Otero and Gayet (1996). The unambiguous synapomorphies that support this relationship are the losses of the anterior supramaxilla $\left(4^{1}\right)$, of the basisphenoid $\left(11^{1}\right)$, and of one epural $\left(46^{1}\right)$.

The characters that unite $\uparrow P y c n o s t e r o i d e s, ~ † O m o s o m o p s i s$, and Polymixia according to recent taxonomic revisions (Taverne, 2011; Murray and Wilson, 2014) are the long neural spine on NPU2 and the 18 principal caudal rays, two character states that are shown here to be synapomorphies of the larger Clade B. In the light of these results, it appears that a redefinition of the composition and synapomorphies of a putative Polymixiiformes clade (including other early fossil taxa, not analyzed here) is much needed. 
Percopsiformes, Gadiformes, and Zeiformes Clade

Our analyses did not recover a clade Paracanthopterygii sensu Patterson and Rosen (1989). In Analysis 1, Gadiformes and Percopsiformes form a clade with Zeiformes and Stylephorus, instead of Ophidiiformes and Batrachoidiformes, themselves nested within Percomorpha in clade A (Figure 4).

$\dagger$ Sphenocephalus is recovered here as the sister to Percopsiformes + Gadiformes + Zeiformes, echoing earlier works (Otero and Gayet, 1996; Murray and Wilson, 1999; Grande et al., 2013; Davesne et al., 2014). The characters that support this relationship are the presence of a notch in the postmaxillary process of the premaxilla $\left(3^{1}\right)$-the socalled "gadoid" notch (Figure 7A), and of no more than one supraneural bone in front of the dorsal fin $\left(31^{2}\right)$.

Percopsiformes is sister to Gadiformes, Zeiformes, and Stylephorus, in congruence with several molecular datasets (Dettai and Lecointre, 2005; Broughton, 2010; Betancur-R et al., 2013; Grande et al., 2013; Chen et al., 2014). The synapomorphies of this clade are the absence of supramaxillae $\left(5^{1}\right)$, the fusion of the second ural centrum with the upper hypurals while staying autogenous from the first ural centrum $\left(42^{1}\right)$, and the fusion of proximal and distal postcleithra $\left(53^{1}\right)$. All these three characters are convergent with Lampridiformes and Batrachoidiformes. In addition, the monophyly of Percopsiformes is recovered here and supported by three unambiguous synapomorphies; it was also previously recovered with molecular data (Dillman et al., 2011; Grande et al., 2013), but was ambiguous with morphology (Patterson and Rosen, 1989; Murray and Wilson, 1999).

The Gadiformes + Zeiformes clade (also including Stylephorus, see below) is supported by no less than nine unambiguous synapomorphies, including the loss of palatine teeth $\left(20^{1}\right)$, the shortening of the second vertebral centrum $\left(30^{1}\right.$; Figure $\left.7 \mathbf{B}\right)$ - previously used as a synapomorphy of Ophidiiformes + Gadiformes + Batrachoidiformes + Lophiiformes, and the close association between the first neural spine and the neurocranium $\left(29^{1}\right.$; Figure $\left.7 \mathbf{B}\right)$-previously used as a Gadiformes + Batrachoidiformes + Lophiiformes synapomorphy (Patterson and Rosen, 1989). Another potential synapomorphy (not included in our study due to lacking fresh material for dissection in many taxa) is the presence, in both Gadiformes and Zeiformes, of intrinsic sonic muscles limited to the anterior end of the swim bladder (Kasumyan, 2008).

\section{Stylephorus with Gadiformes and Zeiformes}

The present phylogenetic analysis of morphological characters is the first to include Stylephorus alongside lampridiforms and acanthomorph representatives. In agreement with all molecular studies, Stylephorus is included within clade B alongside Gadiformes and Zeiformes, instead of within Lampridiformes. However, it is recovered here as sister to Zeiformes (Figure 4), whereas molecular data suggest a closer relationship with Gadiformes (e.g., Miya et al., 2007). This Stylephorus-Zeiformes relationship is supported by four unambiguous synapomorphies: The ascending processes of the premaxillae are longer than the articular processes $\left(1^{1}\right)$, the soft rays of the dorsal, anal $\left(41^{1}\right)$, and pectoral $\left(56^{1}\right)$ fins are unbranched and there is no contact between the quadrate and the reduced metapterygoid $\left(18^{1}\right)$. The latter two synapomorphies are unique for this clade, and therefore not found in any gadiform or lampridiform. In addition, the first vertebra of Stylephorus is much reduced and its neural spine is closely associated with the neurocranium $\left(29^{1}\right)$, a Gadiformes + Zeiformes synapomorphy (Figure 7B) also absent in Lampridiformes.

Conversely, several synapomorphies that are exclusive to Lampridiformes are absent in Stylephorus: It lacks the frontal vault $\left(15^{1}\right)$, the condylar articulation between the anterior ceratohyal and the ventral hypohyal $\left(22^{1}\right.$; Figure 8), and its first dorsal pterygiophore is not inserted anterior to the first neural spine $\left(33^{2}\right)$. It also has four autogenous pectoral radials, instead of the three $\left(55^{1}\right)$ that are observed in all lampridiforms except for Veliferidae. The presence of exclusive Gadiformes + Zeiformes synapomorphies, combined with the absence of several exclusive lampridiform synapomorphies (all the other ones being either ambiguously present, or

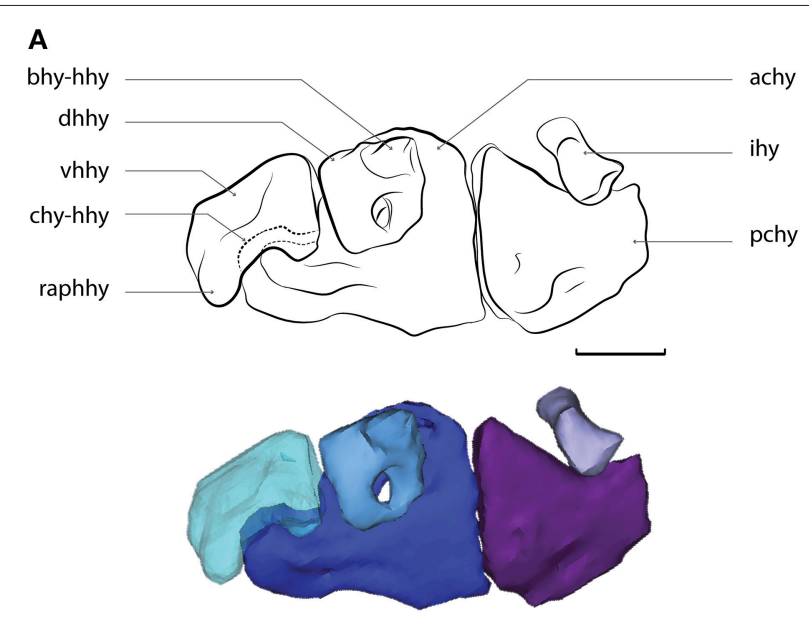

B

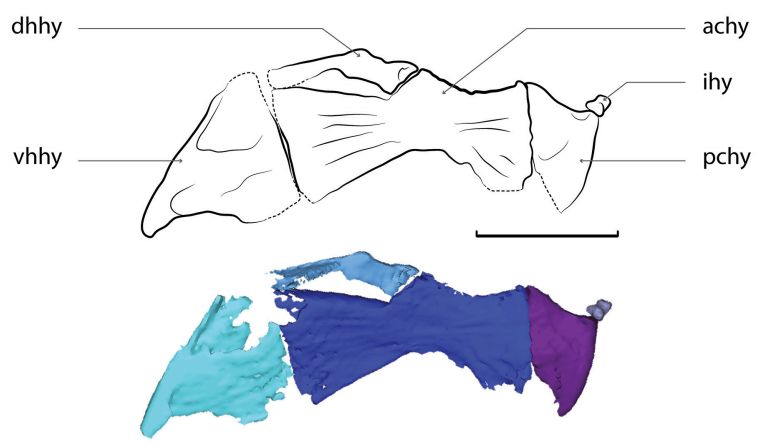

FIGURE 8 | (A) Velifer hypselopterus, MNHN.IC.1982.0025, reconstructed from virtual tomographic data. Ventral portion of the left hyoid arch, in medial view, reversed (anterior faces left). (B) Stylephorus chordatus,

MNHN.IC.2004.1317, reconstructed from virtual tomographic data. Ventral portion of the left hyoid arch, in medial view, reversed (anterior faces left). Abbreviations: achy, anterior ceratohyal; bhy-hhy, facet of the basihyal-dorsal hypohyal articulation; chy-hhy, condyle of the anterior ceratohyal-ventral hypohyal articulation; dhhy, dorsal hypohyal; ihy, interhyal; pchy, posterior ceratohyal; raphhy, retro-articular process of the ventral hypohyal; vhhy, ventral hypohyal. Scale bar equals $2 \mathrm{~mm}$. 
convergent in Stylephorus) strongly support the hypothesis of a close relationship between Gadiformes, Zeiformes, and Stylephorus.

\section{Clade A: Beryciformes, Ophidiiformes, and Batrachoidiformes}

The monophyly of Clade A is supported by numerous synapomorphies. These include the double-headed craniohyomandibular articulation $\left(17^{0}\right.$; Figure 9A), the presence of antero-median pelvic processes $\left(58^{1}\right)$, and a Baudelot's ligament inserting proximally on the basioccipital rather than on anterior vertebrae $\left(25^{1}\right)$. In Zeus and Velifer, a non-homologous condition shows the ligament inserting on the exoccipitals, instead of on the basioccipital as it is the case in members of Clade A. The peculiar, "chain-link" articulation of the dorsal-fin spines $\left(36^{1}\right)$, and the asymmetric base of the pelvic spines $\left(66^{1}\right.$, Figure $\left.9 \mathrm{~B}\right)$ are also unique to Clade A (Mok and Chang, 1986), but optimized ambiguously at this node due to missing data in fossils. Finally, the pelvic-fin spine $\left(65^{1}\right.$; Figure 9B), a diagnostic "acanthopterygian" character according to Greenwood et al. (1966), has an ambiguous phylogenetic history with our topology: It could either be a synapomorphy of Clade A convergent with $\dagger$ Pycnosteroides and Zeiformes, or a synapomorphy of Clade A + Clade B (with multiple secondary losses).

Within Clade A, "beryciforms" are recovered as paraphyletic: The holocentrid Sargocentron is more closely related to percomorphs than to the trachichthyid Hoplostethus (Figure 4). Indeed, Sargocentron and percomorphs share a separate, entirely spinous anterior dorsal fin $\left(37^{1}\right.$; Figures $\left.\mathbf{2 M , N}\right)$ - with multiple reversions within percomorphs, the fusion of the ural centra together and with the upper hypurals $\left(42^{1}, 43^{1}\right)$ and the reduction in the number of hypurals $\left(49^{1}\right)$.

Finally, Percomorpha includes Ophidiiformes (Brotula) and Batrachoidiformes (Halobatrachus), congruent with every molecular study including these taxa together. However, it should be kept in mind that we used a very limited taxon sampling for Percomorpha, and that expanding it might have changed the resulting topology. Batrachoidiformes and Ophidiiformes share several synapomorphies with the other members of Clade A, such as the two hyomandibular heads (there is only one in most members of Clade B, see Figure 9A), the insertion of the Baudelot's ligament on the basioccipital (rather than on the exoccipitals or vertebrae), the asymmetrical pelvic spine base (Figure 9B; the pelvic spine is present but extremely reduced in Ophidiiformes) and-only in Batrachoidiformesthe spinous anterior dorsal fin (Figure 2L). In addition, Brotula possesses a supramaxilla, a basisphenoid and palatine teeth, all lost within Clade B (see above). Our findings parallel those of previous authors (Gosline, 1968; Fraser, 1972; Gill, 1996; Wiley and Johnson, 2010) who viewed these character observations as potential challenges to the monophyly of "Paracanthopterygii."

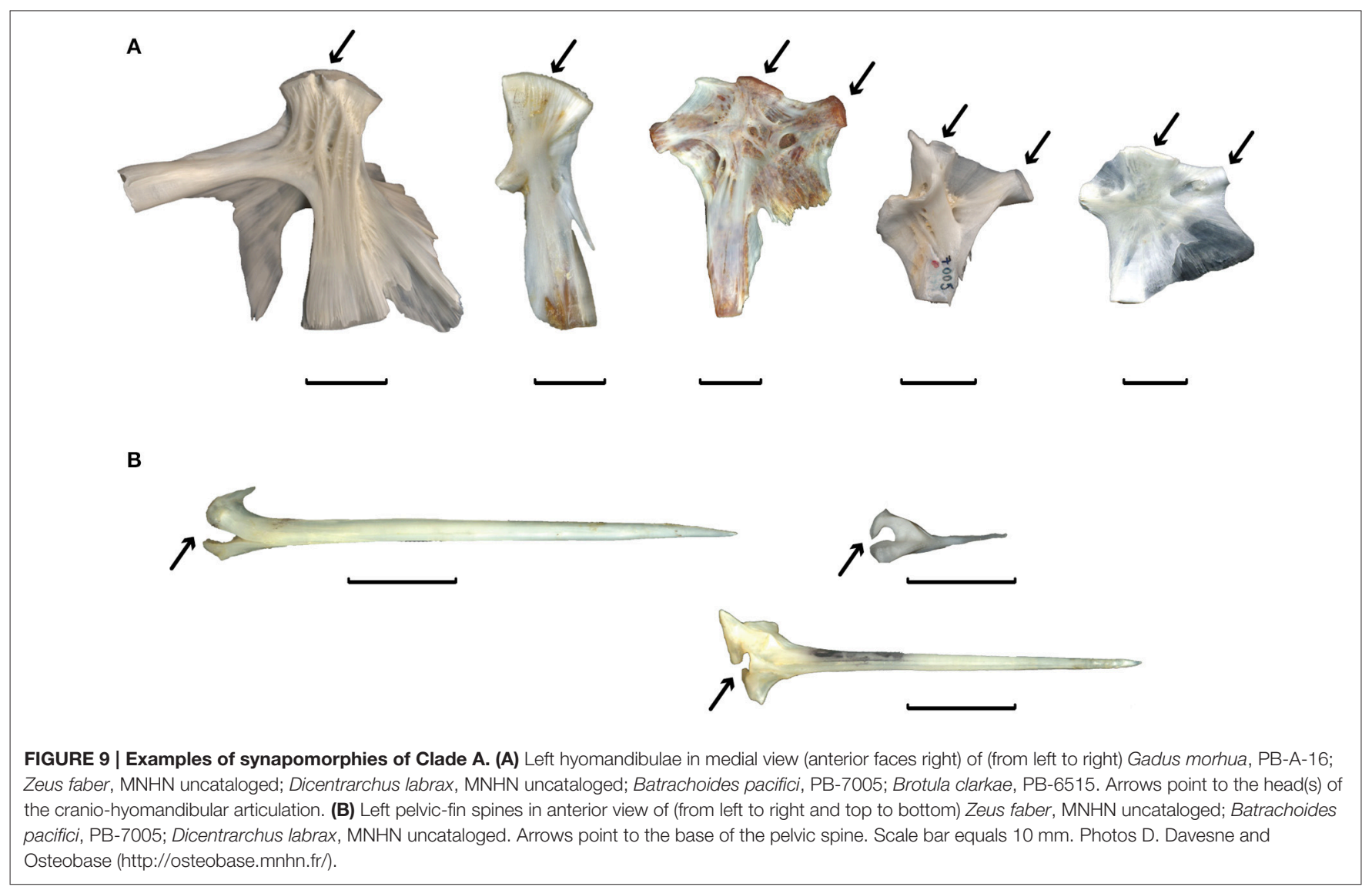




\section{Congruence with Molecular Results}

Table 1 summarizes the topologies found by relevant morphological and molecular phylogenetic analyses. It shows that molecular analyses since 2005 have systematically agreed on a number of points, namely the rejection of a paracanthopterygian clade, the monophyly of a Gadiformes + Zeiformes clade (that also includes Stylephorus) and the inclusion of Ophidiiformes and Batrachoidiformes within Percomorpha. All of these results are also recovered in our Analysis 1 (Figure 4).

Only two minor conflicts remain between our topology and this molecular "consensus": Stylephorus is sister to Zeiformes, instead of Gadiformes; and Ophidiiformes and Batrachoidiformes form a clade together, instead of being sequential sister groups with other percomorphs. However, our percomorph sampling is much reduced and not suitable for providing an effective test of percomorph interrelationships.

Already well-supported by their repetition from one dataset to another, the clades found in the "molecular consensus" are hereby corroborated by a diverse set of morphological characters (Table 1).

Some results are not recovered in every molecular study (Table 1), for example: The monophyly of Acanthomorpha and the sister group relationship of Lampridiformes with other acanthomorphs (corroborated by our results), the monophyly of Beryciformes (not corroborated by our results), the grouping of Percopsiformes with Gadiformes + Zeiformes and of this ensemble with Polymixiiformes (both corroborated by our results). However, it should be noted that these conflicting nodes are commonly associated with comparatively low support values (bootstrap indexes and/or posterior probabilities) in molecular studies. Therefore, these clades are neither robust, nor repeated, a combination that should be sufficient to not accept them directly (Chen et al., 2003; Li and Lecointre, 2009). By contrast, the nonmonophyly of acanthomorphs is an example of relationship that is simultaneously robust and not repeated. The Lampridiformes + Myctophiformes clade of Miya et al. (2005) has a posterior probability of 0.99 or 1 . However, it is never repeated in analyses based on nuclear markers only, nor in another study that used the mitochondrial genome (Broughton, 2010). Assessing in which way gene sampling affects phylogenetic reconstruction in this zone of the tree should be the subject of later investigation.

\section{The Impact of Fossil Taxa}

Our Analysis 2 of extant taxa alone (Figure 5A) fails to recover clades that are always present with molecular results, for example a monophyletic Clade A or a Gadiformes + Zeiformes clade. Two of the three main acanthomorph clades of Analysis 1 are not recovered by this analysis: Clade $\mathrm{A}$ is paraphyletic and includes part of Clade B and Lampridiformes, while Clade B is polyphyletic (Polymixia and Percopsiformes are separated from Gadiformes, Zeiformes, and Stylephorus, the latter three forming a clade with Lampridiformes). Lampridomorpha (reduced to extant Lampridiformes) is monophyletic, but with different intrarelationships (Regalecus is sister to Velifer + Lampris). On the other hand, when fossil taxa are analyzed alone (Figure 5B), they show the same pattern of interrelationships as with Analysis 1.

What is shown here is a possible case of "character extinction," where many character state combinations were present in the earliest members of a group, but disappeared since, due to either the extinction of the taxa that bore them, or extensive subsequent morphological evolution. This is for example the case in Lampridomorpha, whose extant representatives (Lampridiformes) are both relatively less diverse (due to the extinction of many clades at the end of the Cretaceous), and very anatomically-distinctive compared with the oldest known members of the clade (Delbarre et al., 2016). Omitting the early fossil taxa from the analyses can then have an effect similar to the "long branch attraction" that is commonly described in molecular phylogenetics, with extant taxa artificially grouped together on the basis of similar character state combinations, that are recovered here as non-homologous. An example occurs with Lampridiformes, Gadiformes, Zeiformes, and Stylephorus, that are grouped together by numerous synapomorphies in Analysis 2, but are widely separated by fossil representatives in Analysis 1. A similar phenomenon is observed by Davesne et al. (2014) when fossil taxa are not included.

Our results show yet another empirical example in which morphological phylogenetic analyses including fossil and extant taxa achieve a higher congruence with molecular topologies compared with analyses that include only extant taxa. Similar results have been found previously for the deep intrarelationships of amniotes (Gauthier et al., 1988; Donoghue et al., 1989), arthropods (Legg et al., 2013), and annelids (Parry et al., 2016).

\section{CONCLUSION AND PERSPECTIVES}

In the present study, we provide a morphological dataset of extant and fossil taxa that consolidates our current understanding of the earliest stages of acanthomorph evolution. The phylogeny we recover is consistent with topologies proposed by the multiple molecular analyses available today (Table 1), contributing to an integrative view of the interrelationships of this important clade. This congruence is a strong case that morphology can accurately resolve deep phylogenetic relationships. Through this first attempt at covering acanthomorph diversity, we show that even well-known morphological characters can bring valuable support to enduring phylogenetic questions as long as a relevant coverage of the topology (including fossil taxa) is provided. A good example of this is our strong support of a clade including Gadiformes and Zeiformes, permitted by including both taxa in an analysis of morphological characters for the first time.

Analyses of morphological characters in fossil and extant taxa should continue to be performed, even when molecular data are available, due to their key role in: (1) corroborating the molecular results with independent character sets, which increases the reliability of the repeated clades (Grande, 1994; Miyamoto and Fitch, 1995; Chen et al., 2003); (2) providing a framework for the evolution of morphological characters; (3) integrating taxon and character evolution in deep time, by explicitly supporting phylogenetic positions for fossil taxa that 
TABLE 1 | Summary of the main studies presented in this article, and associated phylogenetic hypotheses.

\begin{tabular}{|c|c|c|c|c|c|c|c|c|c|}
\hline & \multicolumn{2}{|c|}{$\begin{array}{l}\text { Stiassny and } \\
\text { Moore, } 1992\end{array}$} & \multicolumn{2}{|c|}{$\begin{array}{l}\text { Johnson and } \\
\text { Patterson, } 1993\end{array}$} & $\begin{array}{l}\text { Patterson and } \\
\text { Rosen, } 1989\end{array}$ & \multicolumn{2}{|l|}{ Wiley et al., 2000} & $\begin{array}{l}\text { Miya et al., } \\
2005 / 2007\end{array}$ & Broughton, 2010 \\
\hline Clades tested & \multicolumn{2}{|c|}{$\begin{array}{l}\text { Morphology } \\
\text { (pelvic girdle only) }\end{array}$} & \multicolumn{2}{|c|}{ Morphology } & Morphology & \multicolumn{2}{|c|}{$\begin{array}{l}\text { Morphology + } 1 \text { mitoch. } \\
+1 \text { nuclear rDNAs }\end{array}$} & $\begin{array}{l}\text { Complete } \\
\text { mitogenomes }\end{array}$ & $\begin{array}{l}\text { Protein-coding } \\
\text { mitochondrial genes }\end{array}$ \\
\hline Acanthomorpha & \multicolumn{2}{|l|}{ Yes } & \multicolumn{2}{|l|}{ Yes } & $\begin{array}{l}\text { Outgroups } \\
\text { absent }\end{array}$ & \multicolumn{2}{|l|}{ Yes } & No & Yes \\
\hline Clade A + Clade B & \multicolumn{2}{|c|}{ Ambiguous } & \multicolumn{2}{|l|}{ Yes } & La. absent & \multicolumn{2}{|l|}{ Yes } & $\begin{array}{l}\text { Yes (La. outside } \\
\text { Acanthomorpha) }\end{array}$ & Yes \\
\hline La. + Pe. + Ga. + Ze. & \multicolumn{2}{|c|}{ No-Ga. absent } & \multicolumn{2}{|c|}{ No-Ga. absent } & La., Ze. absent & \multicolumn{2}{|l|}{ No } & No & No \\
\hline La. + Clade A & \multicolumn{2}{|c|}{ Ambiguous } & \multicolumn{2}{|l|}{ No } & La. absent & \multicolumn{2}{|l|}{ No } & No & No \\
\hline $\begin{array}{l}\text { Po. + Pe. + Ga. + Ze. } \\
\text { (Clade B) }\end{array}$ & \multicolumn{2}{|c|}{ No-Ga. absent } & \multicolumn{2}{|c|}{ No-Ga. absent } & No & \multicolumn{2}{|l|}{ No } & Yes & Yes \\
\hline Po. + Pe. & \multicolumn{2}{|c|}{ Ambiguous } & \multicolumn{2}{|l|}{ No } & No & \multicolumn{2}{|l|}{ No } & Yes & No \\
\hline Pe. + Ga. + Ze. & \multicolumn{2}{|c|}{ No-Ga. absent } & \multicolumn{2}{|c|}{ No-Ga. absent } & Ze. absent & \multicolumn{2}{|l|}{ No } & No & Yes \\
\hline Pe. + Ga. + Op. + Ba. & Assur & d yes & Assum & yes & Yes & No & & No & No \\
\hline Ga. + Ze. & Ga. a & & Ga. $a b$ & & Ze. absent & Yes & & Yes & Yes \\
\hline $\begin{array}{l}\text { Stylephorus + Ga. + } \\
\text { Ze. }\end{array}$ & $\begin{array}{l}\text { Stylep } \\
\text { Ga. a }\end{array}$ & $\begin{array}{l}\text { rus and } \\
\text { ent }\end{array}$ & $\begin{array}{l}\text { Styleph } \\
\text { Ga. } a b\end{array}$ & $\begin{array}{l}\text { us and } \\
\text { tt }\end{array}$ & $\begin{array}{l}\text { Stylephorus and } \\
\text { Ze. absent }\end{array}$ & Stylephorus absent & & Yes (2007 only) & Stylephorus absent \\
\hline Clade A & No & & Yes & & Assumed yes & Yes & & Yes & Yes \\
\hline Ze. + Clade A & Yes & & Yes & & Assumed yes & No & & No & No \\
\hline Beryciformes & No & & Yes & & Absent & No & & Yes & Yes \\
\hline Op. in Percomorpha & Assur & d no & Assum & no & No & Yes & & Yes & Yes \\
\hline Ba. in Percomorpha & Assur & d no & Assum & no & No & Yes & & Yes & Ba. absent \\
\hline & & Li et al., & 09 & Grande & t al., 2013 & Near et al., 2013 & $\begin{array}{l}\text { Bet } \\
201\end{array}$ & ncur-R et al., & Chen et al., 2014 \\
\hline Clades tested & & 4 nuclea & larkers & 4 nucles & 3 mitoch. markers & $\begin{array}{l}10 \text { nuclear } \\
\text { markers }\end{array}$ & $20 r$ & clear markers & $\begin{array}{l}6 \text { nuclear/3 } \\
\text { mitochondrial markers }\end{array}$ \\
\hline Acanthomorpha & & Ambiguo & & yes & & Yes & Yes & & $\begin{array}{l}\text { No with RY-coding/ } \\
\text { yes without }\end{array}$ \\
\hline Clade A + Clade B & & No & & Yes (usi & parsimony) & No & No & & No \\
\hline La. + Pe. + Ga. + Ze. & & Yes + Pc & & No & & No & Yes & & $\begin{array}{l}\text { No with RY-coding/ } \\
\text { yes without }\end{array}$ \\
\hline La. + Clade A & & No & & Yes (usi & likelihood) & Yes & No & & No \\
\hline Po. + Pe. + Ga. + Ze. (C & de B) & Yes + La & & Yes & & No & No & & Yes \\
\hline Po. + Pe. & & No & & No & & Yes & No & & No \\
\hline Pe. + Ga. + Ze. & & No & & Yes & & No & Yes & & Yes \\
\hline Pe. + Ga. + Op. + Ba. & & No & & No & & No & No & & No \\
\hline Ga. + Ze. & & Yes & & Yes & & Yes & Yes & & Yes \\
\hline Stylephorus + Ga. + Ze. & & $\begin{array}{l}\text { Stylepho } \\
\text { absent }\end{array}$ & & Yes & & Yes & Yes & & Stylephorus absent \\
\hline Clade A & & Yes & & Yes & & Yes & Yes & & Yes \\
\hline Ze. + Clade A & & No & & No & & No & No & & No \\
\hline Beryciformes & & No & & Yes & & Yes & No & & No \\
\hline Op. in Percomorpha & & Yes & & Yes & & Yes & Yes & & Yes \\
\hline Ba. in Percomorpha & & Yes & & Yes & & Yes & Yes & & Yes \\
\hline
\end{tabular}

\begin{tabular}{|c|c|c|c|}
\hline & Molecular "consensus" & Present analysis-complete & Present analysis-no fossils \\
\hline Clades tested & & Morphology & Morphology \\
\hline Acanthomorpha & Ambiguous & Yes & Yes \\
\hline Clade A + Clade B & Ambiguous & Yes & No \\
\hline La. + Pe. + Ga. + Ze. & Ambiguous & No & No \\
\hline La. + Clade A & Ambiguous & No & No \\
\hline
\end{tabular}




\begin{tabular}{llll}
\hline & Molecular "consensus" & Present analysis-complete & Present analysis-no fossils \\
\hline Po. + Pe. + Ga. + Ze. (Clade B) & Ambiguous & Yes & No \\
Po. + Pe. & Ambiguous & No & Ambiguous \\
Pe. + Ga. + Ze. & Ambiguous & Yes & No \\
Pe. + Ga. + Op. + Ba. & No & No & No \\
Ga. + Ze. & Yes & Yes & No \\
Stylephorus + Ga. + Ze. & Yes & Yes & No \\
Clade A & Yes & Yes & No \\
Ze. + Clade A & No & No & No \\
Beryciformes & Ambiguous & No & No \\
Op. in Percomorpha & Yes & Yes & No \\
Ba. in Percomorpha & Yes & Yes & No
\end{tabular}

Ba., Batrachoidiformes; Ga., Gadiformes; La., Lampridiformes; Op., Ophidilformes; Pe., Percopsiformes; Po., Polymixifformes; Ze., Zeiformes.

could be subsequently used for divergence time analyses-either directly or as calibration points (Benton and Donoghue, 2007; Parham et al., 2012; Sauquet, 2013).

A more generalized and fruitful dialogue between morphology and molecular data is needed in phylogenetics. Molecular analyses may provide a broad and detailed phylogenetic framework, but maintaining a lively research program in morphology is still necessary in order to provide independent evidence to the molecular phylogenies and, more generally, to understand the history of the relationships between forms and functions in an evolutionary context (Giribet, 2015; Lee and Palci, 2015).

\section{AUTHOR CONTRIBUTIONS}

Designed the study: DD, CG, PJ, GL, and OO. Designed the character list: DD, VB, and OO. Performed the analyses: DD and CG. Wrote the paper: DD, CG, and OO. Reviewed, corrected, and approved the final version of the manuscript: DD, CG, VB, PJ, GL, and $\mathrm{OO}$.

\section{ACKNOWLEDGMENTS}

The authors would like to thank the collection managers that allowed access to the specimens under their care: Philippe Béarez, Gaël Clément, Claude Ferrara, Zora Gabsi, Patrice

\section{REFERENCES}

Alvarado-Ortega, J., and Than-Marchese, B. A. (2012). A Cenomanian aipichthyoid fish (Teleostei, Acanthomorpha) from America, Zoqueichthys carolinae gen. and sp. nov. from El Chango quarry (Cintalapa Member, Sierra Madre Formation), Chiapas, Mexico. Rev. Mex. Cienc. Geol. 29, 735-748.

Benton, M. J., and Donoghue, P. C. J. (2007). Paleontological evidence to date the tree of life. Mol. Biol. Evol. 24, 26-53. doi: 10.1093/molbev/msl150

Benton, M. J., Donoghue, P. C. J., Asher, R. J., Friedman, M., Near, T. J., and Vinther, J. (2015). Constraints on the timescale of animal evolutionary history. Palaeontol. Electron. 18.1.1FC, 1-106.
Pruvost (MNHN), Emma Bernard, Zerina Johanson, James Maclaine, Martha Richter (NHMUK), Markus A. Krag (ZMUC), Radford Arrindell (AMNH), and Rivka Rabinovich (HUJ). We also sincerely thank the following for fruitful discussion on morphological characters and their coding: Ralf Britz (NHMUK), Giorgio Carnevale (Università degli Studi di Torino), Bruno Chanet (MNHN), Matt Friedman (University of Oxford), G. David Johnson (National Museum of Natural History, Smithsonian Institution), and Nalani Schnell (MNHN). CTscan data was acquired at the AST-RX platform (UMS 2700 OMSI, Muséum national d'Histoire naturelle) with the help of Miguel García-Sanz. Iconography was kindly provided by Samuel Iglésias, Christian Lemzaouda, Philippe Loubry, and Nalani Schnell (MNHN), as well as by Philippe Béarez and the Osteobase team (http://osteobase.mnhn.fr/). Roger Close (University of Oxford) is warmly thanked for reviewing the English of the manuscript. DD was supported financially by the ATM "Formes possibles, formes réalisées" (MNHN) and by the Natural Environment Research Council, grant no. NE/J022632/1 (to Matt Friedman, University of Oxford).

\section{SUPPLEMENTARY MATERIAL}

The Supplementary Material for this article can be found online at: http://journal.frontiersin.org/article/10.3389/fevo. 2016.00129/full\#supplementary-material

Betancur-R, R., Broughton, R. E., Wiley, E. O., Carpenter, K., López, J. A., Li, C., et al. (2013). The tree of life and a new classification of bony fishes. PLoS Curr. 18:53ba26640df0ccaee75bb165c8c26288. doi: 10.1371/currents.tol.53ba26640df0ccaee75bb165c8c26288

Betancur-R, R., Wiley, E. O., Bailly, N., Miya, M., Lecointre, G., and Ortí, G. (2014). Phylogenetic Classification of Bony Fishes-version 3. Available online at: https:// sites.google.com/site/guilleorti/home/classification

Borden, W. C., Grande, T., and Smith, W. L. (2013). "Comparative osteology and myology of the caudal fin in the Paracanthopterygii (Teleostei: Acanthomorpha)," in Mesozoic Fishes 5-Global Diversity and Evolution, eds G. Arratia, H.-P. Schultze, and M. V. H. Wilson (Munich: Verlag Dr. Friedriech Pfeil), 419-455. 
Broughton, R. E. (2010). "Phylogeny of teleosts based on mitochondrial genome sequences," in Origin and Phylogenetic Interrelationships of Teleosts, eds J. S. Nelson, H.-P. Schultze, and M. V. H. Wilson (Munich: Verlag Dr. Friedriech Pfeil), 61-76.

Chanet, B., Guintard, C., Betti, E., Gallut, C., Dettai, A., and Lecointre, G. (2013). Evidence for a close phylogenetic relationship between the teleost orders Tetraodontiformes and Lophiiformes based on an analysis of soft anatomy. Cybium 37, 179-198.

Chanet, B., Guintard, C., Boisgard, T., Fusellier, M., Tavernier, C., Betti, E., et al. (2012). Visceral anatomy of ocean sunfish (Mola mola (L., 1758), Molidae, Tetraodontiformes) and angler (Lophius piscatorius (L., 1758), Lophiidae, Lophiiformes) investigated by non-invasive imaging techniques. C. R. Biol. 335, 744-752. doi: 10.1016/j.crvi.2012.11.006

Chen, W.-J., Bonillo, C., and Lecointre, G. (2003). Repeatability of clades as a criterion of reliability: a case study for molecular phylogeny of Acanthomorpha (Teleostei) with larger number of taxa. Mol. Phylogenet. Evol. 26, 262-288. doi: 10.1016/S1055-7903(02)00371-8

Chen, W. J., Ortí, G., and Meyer, A. (2004). Novel evolutionary relationship among four fish model systems. Trends Genet. 20, 424-431. doi: 10.1016/j.tig.2004.07.005

Chen, W.-J., Santini, F., Carnevale, G., Chen, J.-N., Liu, S.-H., Lavoué, S., et al. (2014). New insights on early evolution of spiny-rayed fishes (Teleostei: Acanthomorpha). Front. Mar. Sci. 1:53. doi: 10.3389/fmars.2014.00053

Cobbett, A., Wilkinson, M., and Wills, M. A. (2007). Fossils impact as hard as living taxa in parsimony analyses of morphology. Syst. Biol. 56, 753-766. doi: 10.1080/10635150701627296

Colgan, D. J., Zhang, C.-G., and Paxton, J. R. (2000). Phylogenetic investigations of the Stephanoberyciformes and Beryciformes, particularly whalefishes (Euteleostei: Cetomimidae), based on partial 12S rDNA and 16S rDNA sequences. Mol. Phylogenet. Evol. 17, 15-25. doi: 10.1006/mpev.2000.0811

Davesne, D., Friedman, M., Barriel, V., Lecointre, G., Janvier, P., Gallut, C., et al. (2014). Early fossils illuminate character evolution and interrelationships of Lampridiformes (Teleostei, Acanthomorpha). Zool. J. Linn. Soc. 172, 475-498. doi: 10.1111/zoj.12166

Delbarre, D. J., Davesne, D., and Friedman, M. (2016). Anatomy and relationships of †Aipichthys pretiosus and †'Aipichthys' nuchalis (Acanthomorpha: Lampridomorpha), with a review of Late Cretaceous relatives of oarfishes and their allies. J. Syst. Palaeontol. 14, 545-567. doi: 10.1080/14772019.2015.1078538

Dettai, A., and Lecointre, G. (2004). In search of notothenioid (Teleostei) relatives. Antarct. Sci. 16, 71-85. doi: 10.1017/S095410200400183X

Dettai, A., and Lecointre, G. (2005). Further support for the clades obtained by multiple molecular phylogenies in the acanthomorph bush. C. R. Biol. 328, 674-689. doi: 10.1016/j.crvi.2005.04.002

Dillman, C. B., Bergstrom, D. E., Noltie, D. B., Holtsford, T. P., and Mayden, R. L. (2011). Regressive progression, progressive regression or neither? Phylogeny and evolution of the Percopsiformes (Teleostei, Paracanthopterygii). Zool. Scr. 40, 45-60. doi: 10.1111/j.1463-6409.2010.00454.x

Donoghue, M. J., Doyle, J. A., Gauthier, J., Kluge, A. G., and Rowe, T. (1989). The importance of fossils in phylogeny reconstruction. Annu. Rev. Ecol. Syst. 20, 431-460. doi: 10.1146/annurev.es.20.110189.002243

Endo, H. (2002). Phylogeny of the order Gadiformes (Teleostei, Paracanthopterygii). Mem. Grad. Sch. Fish. Sci. Hokkaido Univ. 49, 75-149.

Faircloth, B. C., Sorenson, L., Santini, F., and Alfaro, M. E. (2013). A phylogenomic perspective on the radiation of ray-finned fishes based upon targeted sequencing of ultraconserved elements (UCEs). PLoS ONE 8:e65923. doi: 10.1371/journal.pone.0065923

Fraser, T. H. (1972). Some thoughts about the teleostean fish concept-the Paracanthopterygii. Jpn. J. Ichthyol. 19, 232-242.

Friedman, M. (2010). Explosive morphological diversification of spiny-finned teleost fishes in the aftermath of the end-Cretaceous extinction. Proc. R. Soc. B Biol. Sci. 277, 1675-1683. doi: 10.1098/rspb.2009.2177

Gaudant, M. (1978). Recherches sur l'anatomie et la systématique des Cténothrissiformes et des Pattersonichthyiformes (poissons téléostéens) du Cénomanien du Liban. Mémoires Mus. Natl. Hist. C Sci. Terre 41, 1-124.

Gaudant, M. (1979). Recherches sur les relations phylogénétiques de certains poissons Eurypterygii du Crétacé de la Mésogée occidentale. Comptes Rendus Acad. Sci. D 288, 1047-1050.
Gauthier, J., Kluge, A. G., and Rowe, T. (1988). Amniote phylogeny and the importance of fossils. Cladistics 4, 105-209. doi: 10.1111/j.10960031.1988.tb00514.x

Gayet, M. (1980c). Découverte dans le Crétacé de Hadjula (Liban) du plus ancien Caproidae connu. Etude anatomique et phylogénétique. Bull. Mus. Nat. Hist. $2 \mathrm{C}, 259-269$

Gayet, M. (1980a). Recherches sur l'ichthyofaune cénomanienne des Monts de Judée: les 'acanthoptérygiens'. Ann. Paléontol. 66, 75-128.

Gayet, M. (1980b). Contribution a l'étude anatomique et systématique des poissons cénomamiens du Liban, anciennement placés dans les acanthoptérygiens. Mémoires Mus. Natl. Hist. C Sci. Terre 44, 1-149.

Gayet, M. (1982). Essai de définition des relations phylogénétiques des Holocentroidea nov. et des Trachichthyoidea nov. (Pisces, Acanthopterygii, Béryciformes). Bull. Mus. Natl. Hist. 4C, 21-41.

Gill, A. C. (1996). Comments on an intercalar path for the glossopharyngeal (cranial IX) nerve as a synapomorphy of the Paracanthopterygii and on the phylogenetic position of the Gobiesocidae (Teleostei: Acanthomorpha). Copeia 1996, 1022-1029. doi: 10.2307/1447670

Giribet, G. (2015). Morphology should not be forgotten in the era of genomics-a phylogenetic perspective. Zool. Anz. 256, 96-103. doi: 10.1016/j.jcz.2015.01.003

Goloboff, P. A., Farris, J. S., and Nixon, K. C. (2008) TNT, a free program for phylogenetic analysis. Cladistics 24, 774-786. doi: 10.1111/j.10960031.2008.00217.x

Gosline, W. A. (1963). Considerations regarding the relationships of the percopsiform, cyprinodontiform, and gadiform fishes. Occas. Pap. Mus. Zool. Univ. Mich. 623, 1-38.

Gosline, W. A. (1968). The suborders of Perciform fishes. Proc. U. S. Nat. Museum 124, 1-78. doi: 10.5479/si.00963801.124-3647.1

Grand, A., Zaragüeta-Bagils, R., Vélez, L. M., and Ung, V. (2014). A cladistic re-analysis of the Gadiformes (Teleostei, Paracanthopterygii) using three-item analysis. Zootaxa 3889, 525-552. doi: 10.11646/zootaxa.3889.4.3

Grande, L. (1994). "Repeating patterns in nature, predictability, and 'impact' in science," in Interpreting the Hierarchy of Nature, eds L. Grande and O. Rieppel (New York, NY: Academic Press), 61-84.

Grande, T., Borden, W. C., and Smith, W. L. (2013). "Limits and relationships of Paracanthopterygii: A molecular framework for evaluating past morphological hypotheses," in Mesozoic Fishes 5-Global Diversity and Evolution, eds G. Arratia, H.-P. Schultze, and M. V. H. Wilson (Munich: Verlag Dr. Friedriech Pfeil), 385-418.

Greenwood, P. H., Rosen, D. E., Weitzman, S. H., and Myers, G. S. (1966). Phyletic studies of teleostean fishes, with a provisional classification of living forms. Bull. Am. Mus. Nat. Hist. 131, 341-455.

Holcroft, N. I., and Wiley, E. O. (2008). Acanthuroid relationships revisited: a new nuclear gene-based analysis that incorporates tetraodontiform representatives. Ichthyol. Res. 55, 274-283. doi: 10.1007/s10228-007-0026-x

Iglésias, S. P. (2014). Handbook of the marine fishes of Europe and adjacent waters (a natural classification based on collection specimens, with DNA barcodes and standardized photographs) - Volume II (Actinopterygians) - Provisional version 10. Available online at: http://iccanam.mnhn.fr/GBAccueil.htm

Johnson, G. D. (1992). Monophyly of the euteleostean clades: neoteleostei, Eurypterygii, and Ctenosquamata. Copeia 1992, 8-25. doi: 10.2307/14 46531

Johnson, G. D., and Patterson, C. (1993). Percomorph phylogeny: a survey of acanthomorphs and a new proposal. Bull. Mar. Sci. 52, 554-626.

Kasumyan, A. O. (2008). Sounds and sound production in fishes. J. Ichthyol. 48, 981-1030. doi: 10.1134/S0032945208110039

Lee, M. S. Y., and Palci, A. (2015). Morphological phylogenetics in the genomic age. Curr. Biol. 25, R922-R929. doi: 10.1016/j.cub.2015.07.009

Legg, D. A., Sutton, M. D., and Edgecombe, G. D. (2013). Arthropod fossil data increase congruence of morphological and molecular phylogenies. Nat. Commun 4, 2485. doi: $10.1038 /$ ncomms 3485

Li, B., Dettaï, A., Cruaud, C., Couloux, A., Desoutter-Meniger, M., and Lecointre, G. (2009). RNF213, a new nuclear marker for acanthomorph phylogeny. Mol. Phylogenet. Evol. 50, 345-363. doi: 10.1016/j.ympev.2008. 11.013

Li, B., and Lecointre, G. (2009). Formalizing reliability in the taxonomic congruence approach. Zool. Scr. 38, 101-112. doi: 10.1111/j.14636409.2008.00361.x 
Li, C., Lu, G., and Ortí, G. (2008). Optimal data partitioning and a test case for rayfinned fishes (Actinopterygii) based on ten nuclear loci. Syst. Biol. 57, 519-539. doi: $10.1080 / 10635150802206883$

Malmstrøm, M., Matschiner, M., Tørresen, O. K., Star, B., Snipen, L. G., Hansen, T. F., et al. (2016). Evolution of the immune system influences speciation rates in teleost fishes. Nat. Genet. 48, 1204-1210. doi: 10.1038/ng.3645

Mirande, J. M. (2016). Combined phylogeny of ray-finned fishes (Actinopterygii) and the use of morphological characters in large-scale analyses. Cladistics. doi: 10.1111/cla.12171. [Epub ahead of print].

Miya, M., Holcroft, N. I., Satoh, T. P., Yamaguchi, M., Nishida, M., and Wiley, E. O. (2007). Mitochondrial genome and a nuclear gene indicate a novel phylogenetic position of deep-sea tube-eye fish (Stylephoridae). Ichthyol. Res. 54, 323-332. doi: 10.1007/s10228-007-0408-0

Miya, M., Kawaguchi, A., and Nishida, M. (2001). Mitogenomic exploration of higher teleostean phylogenies: a case study for moderate-scale evolutionary genomics with 38 newly determined complete mitochondrial DNA sequences. Mol. Biol. Evol. 18, 1993-2009. doi: 10.1093/oxfordjournals.molbev.a003741

Miya, M., Satoh, T. P., and Nishida, M. (2005). The phylogenetic position of toadfishes (order Batrachoidiformes) in the higher ray-finned fish as inferred from partitioned Bayesian analysis of 102 whole mitochondrial genome sequences. Biol. J. Linn. Soc. 85, 289-306. doi: 10.1111/j.10958312.2005.00483.x

Miya, M., Takeshima, H., Endo, H., Ishiguro, N. B., Inoue, J. G., Mukai, T., et al. (2003). Major patterns of higher teleostean phylogenies: a new perspective based on 100 complete mitochondrial DNA sequences. Mol. Phylogenet. Evol. 26, 121-138. doi: 10.1016/S1055-7903(02)00332-9

Miyamoto, M. M., and Fitch, W. M. (1995). Testing species phylogenies and phylogenetic methods with congruence. Syst. Biol. 44, 64-76. doi: 10.1093/sysbio/44.1.64

Mok, H., and Chang, H. (1986). Articulation of the pelvic spine in acanthopterygian fishes, with notes on its phylogenetic implications. Jpn. J. Ichthyol. 33, 145-150.

Moore, J. A. (1993). Phylogeny of the Trachichthyiformes (Teleostei: Percomorpha). Bull. Mar. Sci. 52, 114-136.

Murray, A. M., and Wilson, M. V. H. (1999). "Contributions of fossils to the phylogenetic relationships of the percopsiform fishes (Teleostei: Paracanthopterygii): Order restored," in Mesozoic Fishes 2-Systematics and Fossil Record, eds G. Arratia and H.-P. Schultze (Munich: Verlag Dr. Friedriech Pfeil), 397-411.

Murray, A. M., and Wilson, M. V. H. (2014). Four new basal acanthomorph fishes from the Late Cretaceous of Morocco. J. Vertebr. Paleontol. 34, 34-48. doi: 10.1080/02724634.2013.791693

Near, T. J., Dornburg, A., Eytan, R. I., Keck, B. P., Smith, W. L., Kuhn, K. L., et al. (2013). Phylogeny and tempo of diversification in the superradiation of spiny-rayed fishes. Proc. Natl. Acad. Sci. U.S.A. 110, 12738-12743. doi: 10.1073/pnas. 1304661110

Near, T. J., Eytan, R. I., Dornburg, A., Kuhn, K. L., Moore, J. A., Davis, M. P., et al. (2012). Resolution of ray-finned fish phylogeny and timing of diversification. Proc. Natl. Acad. Sci. U.S.A. 109, 13698-13703. doi: 10.1073/pnas.1206625109

Nelson, J. S., Grande, T. C., and Wilson, M. V. H. (2016). Fishes of the World, 5th Edn. Hoboken, NJ: John Wiley \& Sons.

O'Leary, M. A., and Kaufman, S. (2011). MorphoBank: phylophenomics in the 'cloud.' Cladistics 27, 529-537. doi: 10.1111/j.1096-0031.2011.00355.x

O'Leary, M. A., and Kaufman, S. G. (2012). MorphoBank 3.0: Web Application for Morphological Phylogenetics and Taxonomy. Available online at: http://www. morphobank.org

Oelschläger, H. A. (1983). Vergleichende und funktionelle Anatomie der Allotriognathi (= Lampridiformes), ein Beitrag zur Evolutionsmorphologie der Knochenfische. Abhandlungen der Senckenbergischen Naturforschenden Gesellschaft 541, 1-127.

Olney, J. E. (1984). "Lampriformes: development and relationships," in Ontogeny and Systematics of Fishes, eds H. G. Moser, W. J. Richards, D. M. Cohen, M. P. Fahay, A. W. Kendall, and S. L. Richardson (Lawrence, KS: Allen Press), 368-379. Special Publication Number 1, American Society of Ichthyologists and Herpetologists.

Olney, J. E., Johnson, G. D., and Baldwin, C. C. (1993). Phylogeny of lampridiform fishes. Bull. Mar. Sci. 52, 137-169.
Otero, O. (2004). Anatomy, systematics and phylogeny of both Recent and fossil latid fishes (Teleostei, Perciformes, Latidae). Zool. J. Linn. Soc. 141, 81-133. doi: 10.1111/j.1096-3642.2004.00111.x

Otero, O., Dutour, Y., and Gayet, M. (1995). Hgulichthys, nouveau genre de Lissoberycinae (Trachichthyiformes, Trachichthyoidea) du Cénomanien inférieur marin de Hgula (Liban). Implications phylogénétiques. Geobios 28, 711-717. doi: 10.1016/S0016-6995(95)80065-4

Otero, O., and Gayet, M. (1996). Anatomy and phylogeny of the Aipichthyoidea nov. of the Cenomanian Tethys and their place in the Acanthomorpha (Teleostei). Neues Jahrbuch Geol. Paläontol. Abhandlungen 202, 313-344.

Parenti, L. R., and Song, J. (1996). "Phylogenetic significance of the pectoralpelvic fin association in acanthomorph fishes: a reassessment using comparative neuroanatomy," in Interrelationships of Fishes, eds M. L. J. Stiassny, L. R. Parenti, and G. D. Johnson (San Diego, CA: Academic Press), 427-444.

Parham, J. F., Donoghue, P. C. J., Bell, C. J., Calway, T. D., Head, J. J., Holroyd, P. A., et al. (2012). Best practices for justifying fossil calibrations. Syst. Biol. 61, 346-359. doi: 10.1093/sysbio/syr107

Parry, L. A., Edgecombe, G. D., Eibye-Jacobsen, D., and Vinther, J. (2016). The impact of fossil data on annelid phylogeny inferred from discrete morphological characters. Proc. R. Soc. B Biol. Sci. 283:20161378. doi: 10.1098/rspb.2016.1378

Patterson, C. (1964). A review of Mesozoic acanthopterygian fishes, with special reference to those of the English Chalk. Philos. Trans. R. Soc. Lond. B. Biol. Sci. 247, 213-482. doi: 10.1098/rstb.1964.0003

Patterson, C. (1967). New Cretaceous berycoid fishes from Lebanon. Bull. Br. Mus. Geol. 14, 67-109.

Patterson, C. (1993). An overview of the early fossil record of acanthomorphs. Bull. Mar. Sci. 52, 29-59.

Patterson, C., and Rosen, D. E. (1989). The Paracanthopterygii revisited: order and disorder. Sci. Ser. Nat. Hist. Museum (Los Angeles) 32, 5-36.

Pietsch, T. W. (1978). The feeding mechanism of Stylephorus chordatus (Teleostei: Lampridiformes): functional and ecological implications. Copeia 1978, 255-262. doi: 10.2307/1443560

Poulsen, J. Y., Byrkjedal, I., Willassen, E., Rees, D., Takeshima, H., Satoh, T. P., et al. (2013). Mitogenomic sequences and evidence from unique gene rearrangements corroborate evolutionary relationships of Myctophiformes (Neoteleostei). BMC Evol. Biol. 13:111. doi: 10.1186/1471-214813-111

Regan, C. T. (1908). The systematic position of Stylophorus chordatus. Ann. Mag. Nat. Hist. 8, 447-449. doi: 10.1080/00222930808692508

Regan, C. T. (1924). The morphology of a rare oceanic fish, Stylophorus chordatus, Shaw; based on specimens collected in the Atlantic by the 'Dana' Expeditions, 1920-1922. Proc. R. Soc. Lond. B 96, 193-207. doi: 10.1098/rspb.192 4.0021

Roberts, T. R. (2012). Systematics, Biology and Distribution of the Species of the Oceanic Oarfish Genus Regalecus (Teleostei, Lampridiformes, Regalecidae). Paris: Publications Scientifiques du Muséum.

Rosen, D. E. (1973). "Interrelationships of higher euteleostean fishes," in Interrelationships of Fishes, eds P. H. Greenwood, R. S. Miles, and C. Patterson (London: Academic Press), 397-513.

Rosen, D. E. (1984). Zeiforms as primitive plectognath fishes. Am. Mus. Novit. $2782,1-45$

Rosen, D. E. (1985). An essay on euteleostean classification. Am. Mus. Novit. 2827, $1-57$.

Rosen, D. E., and Patterson, C. (1969). The structure and relationships of the paracanthopterygian fishes. Bull. Am. Mus. Nat. Hist. 141, 357-474.

Santini, F., and Tyler, J. C. (2004). The importance of even highly incomplete fossil taxa in reconstructing the phylogenetic relationships of the Tetraodontiformes (Acanthomorpha: Pisces). Integr. Comp. Biol. 44, 349-357. doi: $10.1093 / \mathrm{icb} / 44.5 .349$

Sauquet, H. (2013) A practical guide to molecular dating. C. R. Palevol. 12, 355-367. doi: 10.1016/j.crpv.2013.07.003

Solbakken, M. H., Rise, M. L., Jakobsen, K. S., and Jentoft, S. (2016). Successive losses of central immune genes characterize the Gadiformes' alternate immunity. Genome Biol. Evol. doi: 10.1093/gbe/evw250. [Epub ahead of print]. 
Springer, V. G., and Orrell, T. M. (2004). Phylogenetic analysis of acanthomorph fishes based on dorsal gill-arch muscles and skeleton. Bull. Biol. Soc. Wash. 11, 237-260.

Starks, E. C. (1908). The characters of Atelaxia, a new suborder of fishes. Bull. Mus. Comp. Zool. 52, 17-22.

Stiassny, M. L. J. (1986). The limits and relationships of the acanthomorph teleosts. J. Zool. 1, 411-460. doi: 10.1111/j.1096-3642.1986.tb00644.x

Stiassny, M. L. J. (1996). "Basal ctenosquamate relationships and the interrelationships of the myctophiform (scopelomorph) fishes," in Interrelationships of Fishes, eds M. L. J. Stiassny, L. R. Parenti, and G. D. Johnson (San Diego: Academic Press), 405-426.

Stiassny, M. L. J., and Moore, J. A. (1992). A review of the pelvic girdle of acanthomorph fishes, with comments on hypotheses of acanthomorph intrarelationships. Zool. J. Linn. Soc. 104, 209-242. doi: 10.1111/j.10963642.1992.tb00923.x

Świdnicki, J. (1991). New data on the osteology of some species of Bregmaceros (Teleostei, Gadiformes). J. Morphol. 208, 129-160. doi: 10.1002/jmor.1052080202

Swofford, D. L. (2002). PAUP*, Phylogenetic Analysis Using Parsimony (*and Other Methods), Version 4. Sunderland, MA: Sinauer Associates.

Taverne, L. (2011). Les poissons du Santonien (Crétacé supérieur) d'Apricena (Italie du Sud). $3^{\circ}$. Apricenaichthys italicus gen. et sp. nov. (Teleostei, Polymixiiformes). Boll. Mus. Civico Storia Naturale di Verona Geol. Paleontol. Preistoria 35, 19-31.

Tyler, J. C., O'Toole, B., and Winterbottom, R. (2003). Phylogeny of the genera and families of Zeiform fishes, with comments on their relationships with tetraodontiforms and caproids. Smithson. Contrib. Zool. 618, 1-110. doi: 10.5479/si.00810282.618
Tyler, J. C., and Santini, F. (2005). A phylogeny of the fossil and extant zeiformlike fishes, Upper Cretaceous to Recent, with comments on the putative zeomorph clade (Acanthomorpha). Zool. Scr. 34, 157-175. doi: 10.1111/j.14636409.2005.00180.x

Wiley, E. O., and Johnson, G. D. (2010). "A teleost classification based on monophyletic groups," in Origin and Phylogenetic Interrelationships of Teleosts, eds J. S. Nelson, H.-P. Schultze, and M. V. H. Wilson (Munich: Verlag Dr. Friedriech Pfeil), 123-182.

Wiley, E. O., Johnson, G. D., and Dimmick, W. W. (2000). The interrelationships of Acanthomorph fishes: a total evidence approach using molecular and morphological data. Biochem. Syst. Ecol. 28, 319-350. doi: 10.1016/S03051978(99)00069-1

Yamanoue, Y., Miya, M., Matsuura, K., Yagishita, N., Mabuchi, K., Sakai, H., et al. (2007). Phylogenetic position of tetraodontiform fishes within the higher teleosts: Bayesian inferences based on 44 whole mitochondrial genome sequences. Mol. Phylogenet. Evol. 45, 89-101. doi: 10.1016/j.ympev.2007.03.008

Conflict of Interest Statement: The authors declare that the research was conducted in the absence of any commercial or financial relationships that could be construed as a potential conflict of interest.

Copyright (c) 2016 Davesne, Gallut, Barriel, Janvier, Lecointre and Otero. This is an open-access article distributed under the terms of the Creative Commons Attribution License (CC BY). The use, distribution or reproduction in other forums is permitted, provided the original author(s) or licensor are credited and that the original publication in this journal is cited, in accordance with accepted academic practice. No use, distribution or reproduction is permitted which does not comply with these terms. 